\title{
Pseudomonas syringae pv. tomato DC3000 Uses Constitutive and Apoplast-Induced Nutrient Assimilation Pathways to Catabolize Nutrients That Are Abundant in the Tomato Apoplast
}

\author{
Arantza Rico, and Gail M. Preston \\ Department of Plant Sciences, University of Oxford, South Parks Road, Oxford, OX1 3RB, U.K.
}

Submitted 16 August 2007. Accepted 4 October 2007.

\begin{abstract}
The plant apoplast is the intercellular space that surrounds plant cells, in which metabolic and physiological processes relating to cell wall biosynthesis, nutrient transport, and stress responses occur. The apoplast is also the primary site of infection for hemibiotrophic pathogens such as $P$. syringae, which obtain nutrients directly from apoplastic fluid. We have used apoplastic fluid extracted from healthy tomato leaves as a growth medium for Pseudomonas spp. in order to investigate the role of apoplastic nutrients in plant colonization by Pseudomonas syringae. We have confirmed that apoplast extracts mimic some of the environmental and nutritional conditions that bacteria encounter during apoplast colonization by demonstrating that expression of the plant-induced type III protein secretion pathway is upregulated during bacterial growth in apoplast extracts. We used a modified phenoarray technique to show that apoplast-adapted $P$. syringae pv. tomato DC3000 expresses nutrient utilization pathways that allow it to use sugars, organic acids, and amino acids that are highly abundant in the tomato apoplast. Comparative analyses of the nutrient utilization profiles of the genome-sequenced strains $P$. $s y$ ringae pv. tomato $\mathrm{DC} 3000, P$. syringae pv. syringae $\mathrm{B} 728 \mathrm{a}$, $P$. syringae pv. phaseolicola $1448 \mathrm{~A}$, and the unsequenced strain $P$. syringae pv. tabaci 11528 with nine other genomesequenced strains of Pseudomonas provide further evidence that $P$. syringae strains are adapted to use nutrients that are abundant in the leaf apoplast. Interestingly, $P$. syringae pv. phaseolicola 1448A lacks many of the nutrient utilization abilities that are present in three other $P$. syringae strains tested, which can be directly linked to differences in the $P$. syringae pv. phaseolicola 1448A genome.
\end{abstract}

Additional keywords: Biolog, hrp, Pseudomonas aeruginosa, P. entomophila, P. fluorescens, P. mendocina, P. putida

Pseudomonas syringae is a gram-negative bacterium that infects a wide variety of plants and causes necrotic symptoms in leaves, stems, and fruit. It also can be found growing epiphytically and endophytically on plant foliage without causing disease symptoms (Hirano and Upper 2000). Cool tempera-

Corresponding author: Gail M. Preston; Telephone: +44 (0)1865 275132; Fax: +44 (0)1865 275074; E-mail: gail.preston@plants.ox.ac.uk

* The $\boldsymbol{e}$-Xtra logo stands for "electronic extra" and indicates that three additional tables are published online. tures and humidity promote the multiplication of $P$. syringae, which can enter the plant through natural openings such as stomata and hydathodes or via mechanical wounds. $P$. syringae is considered to be a hemibiotrophic pathogen because it is able to obtain nutrients from living host cells in order to multiply in the apoplast and infect neighboring tissues.

$P$. syringae has been studied extensively as a model pathogen to dissect the molecular mechanisms and co-evolution of pathogenesis and plant disease resistance. The primary mechanism of plant defense against $P$. syringae is a basal defense response that is induced upon detection of conserved microbeassociated molecular patterns (MAMPS) (Mackey et al. 2003). $P$. syringae can suppress basal defenses in susceptible plants by secretion of effector proteins into the cytosol of plant cells. Effector proteins inactivate plant surveillance mechanisms and signal transduction pathways, thereby allowing bacterial growth. Resistant plants frequently express a second type of induced resistance in which plant resistance proteins ( $\mathrm{R}$ proteins) recognize either effectors or their effects on plant cells and trigger immune responses that block pathogen multiplication. These immune responses include a localized cell death response known as the hypersensitive response (HR) (Alfano and Collmer 2004). R protein-dependent defenses have promoted further evolution of $P$. syringae, including the evolution of effectors that suppress effector-triggered immunity (detailed reviews of effector-mediated interactions between $P$. syringae and plants have been published previously) (Alfano and Collmer 2004; Chisholm et al. 2006; Jones and Dangl 2006; Mackey et al. 2003; Nomura et al. 2005).

Although effector proteins are essential for suppressing host basal defenses in the first stages of invasion and for long-term survival in plant tissues, the initial success of $P$. syringae as a plant endophyte depends on its ability to survive and proliferate in the apoplast of healthy plants. This success is likely to be determined at multiple levels: its ability to tolerate preformed defense molecules, its ability to import and metabolize available nutrients, and, ultimately, its ability to express pathogenicity and virulence factors that modulate host defenses and host metabolism. Boch and associates (2002) identified a wide range of plant-induced loci in $P$. syringae pv. tomato DC3000, which included not only virulence-associated genes such as hrp genes and coronatine biosynthesis genes but also genes involved in stress tolerance, polysaccharide synthesis, nutrient uptake, amino acid assimilation, and carbon metabolism.

Most studies on the adaptation of $P$. syringae to the plant apoplast have focused on the expression and regulation of pathogenicity genes, such as the hrp genes that encode the 
type III protein secretion system (TTSS) that delivers effectors into plant cells. In vitro, hrp gene expression is induced by low $\mathrm{pH}$; sugars such as sucrose, fructose, and mannitol; and a low N/C ratio. hrp expression is suppressed by amino acids and tricarboxylic acid cycle (TCA) intermediates, possibly due to catabolite repression (Huynh et al. 1989; Rahme et al. 1992; Xiao et al. 1992). hrp genes are rapidly upregulated when bacteria are infiltrated into plant leaves (Rahme et al. 1992; Xiao et al. 1992), which has been interpreted as indicating that the apoplast provides a similar physiological environment to hrpinducing media, an environment which is acidic, low in nitrogen, and rich in plant-derived sugars such as fructose.

Some evidence for nutritional adaptation to a plant-pathogenic lifestyle in P. syringae comes from taxonomic studies of plant-pathogenic and non-plant-pathogenic pseudomonads, which show that $P$. syringae strains can be identified to a species and pathovar level with a moderate degree of confidence based on their performance in nutrient utilization assays and specific phenotypic tests. These studies have shown that $P$. syringae strains show reduced nutritional versatility when compared with non-plant-pathogenic pseudomonads, particularly with respect to amino acid assimilation (Braun-Kiewnick and Sands 2001; Misaghi and Grogan 1969; Sands et al. 1970; Stanier et al. 1966; Young and Triggs 1994).

Experimental analyses of nutrient utilization by $P$. syringae are supported by bioinformatic analyses of sequenced $P$. syringae genomes. For example, $P$. syringae genomes encode a large number of proteins with predicted functions in sugar transport, but few amino acid permease domain proteins compared with the genomes of other Pseudomonas spp. (Buell et al. 2003; Joardar et al. 2005; Studholme et al. 2005). One hypothesis that could explain both the experimental and bioinformatic information available on nutrient utilization in $P$. syringae is that these bacteria are nutritionally specialized to use a limited set of nutrients that are abundant in the plant apoplast, in leaf exudates, and on the leaf surface. Biochemical analyses of metabolites present in the plant apoplast extracts, in leaf guttation droplets, and on the plant surfaces do indicate that these niches are chemically less diverse than other Pseudomonas habitats, such as the rhizosphere, although the composition of each of these niches varies between different plant species (Andrews and Harris 2000; Goatley and Lewis 1966; Pilot et al. 2004; Solomon and Oliver 2001).

In this study, we have used the interaction between $P$. syringae pv. tomato DC3000 and its host plant tomato as a model system to investigate the physiological adaptation of $P$. syringae to growth in the apoplast, and to assess the ability of $P$. syringae to use nutrients that are abundant in the tomato apoplast. We have used phenoarray technology to profile nutrient utilization by $P$. syringae in synthetic media and in apoplast extracts and have integrated nutrient utilization assays with analyses of apoplast composition, hrp gene expression, and genome sequence data to investigate the links between apoplast composition, host specificity, nutrient utilization, and plant pathogenesis.

\section{RESULTS}

\section{Tomato apoplast extracts provide a complete growth medium for $P$. syringae pv. tomato $\mathrm{DC} 3000$.}

The primary aim of this study was to describe the ability of P. syringae pv. tomato DC3000 to grow in apoplastic fluid, excluding other factors that affect the outcome of $P$. syringaeplant interactions, such as bacterial effectors and induced plant defense responses. Apoplastic fluid was isolated from healthy tomato leaves using the infiltration-centrifugation procedure described by Solomon and Oliver (2002) and Solomon et al. (2003). We analyzed the activity of the cytoplasmic enzymes glucose-6-phosphate dehydrogenase (G6PDH) and malate dehydrogenase $(\mathrm{MDH})$ in apoplast extracts as markers of cyto-
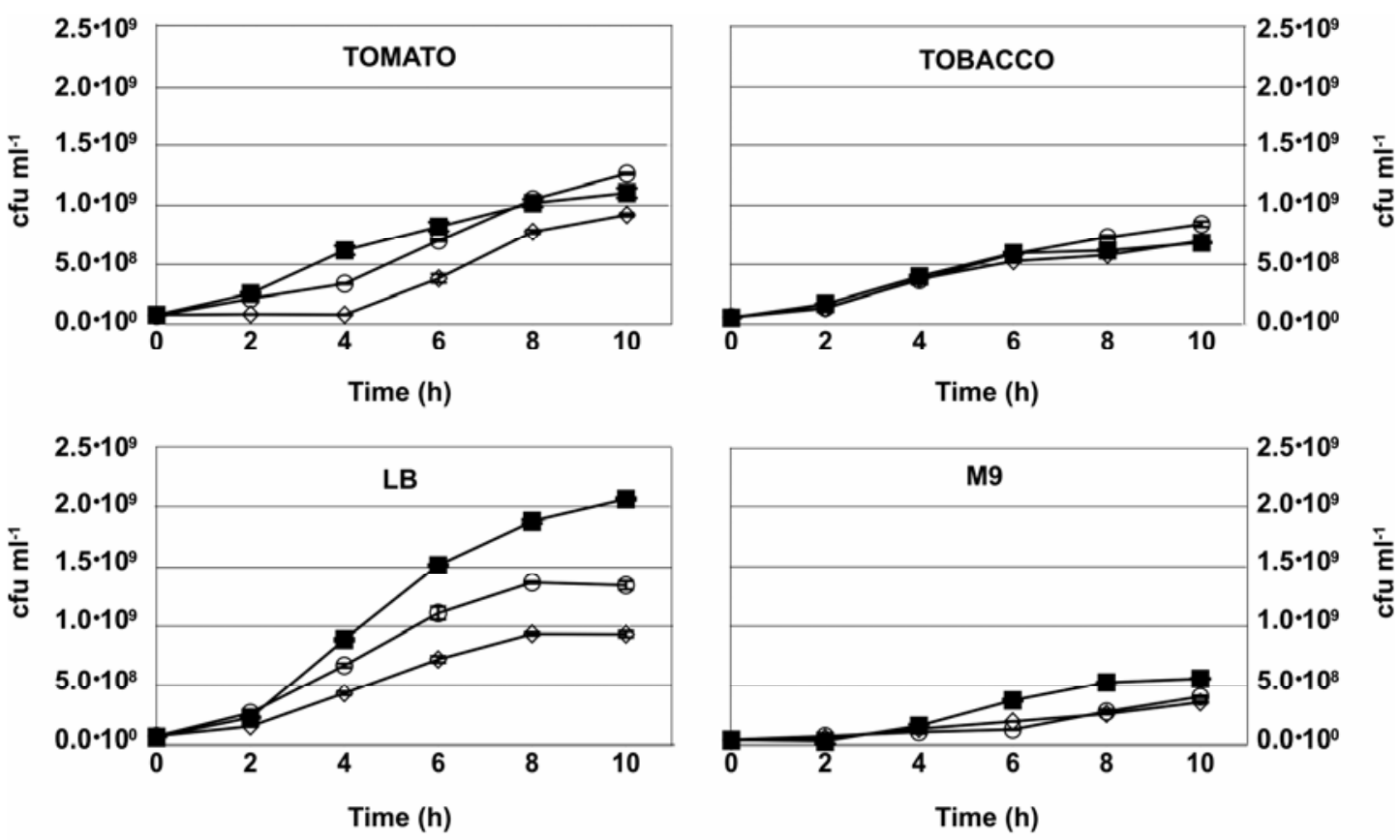

- Pf SBW25 OPsto DC3000 $\diamond$ Psta 11528

Fig. 1. Bacterial growth in apoplast extracts. Pseudomonas syringae pv. tomato DC3000 (open circles), P. syringae pv. tabaci 11528 (open diamonds), and $P$. fluorescens SBW25 (black squares) were grown in vitro in full-strength tomato apoplast extracts (TOMATO), full-strength tobacco apoplast extracts (TOBACCO), rich medium Luria-Bertani (LB) and minimal medium M9. Cultures were incubated in 96-microwell plates in a shaking incubator at $28^{\circ} \mathrm{C}$ and cell density was determined spectrophotometrically at $620 \mathrm{~nm}$. Each value represents the mean of three replicates. Bars designate standard error of the mean. Each graph shows the result of one independent experiment. Each experiment was performed at least twice with similar results. 
plasmic contamination. G6PDH activity in apoplast extracts was undetectable or less than $0.02 \%$ of the activity observed in leaf homogenates $\left(0.250 \pm 0.081 \mu \mathrm{mol} \mathrm{m^{-1 }} \mathrm{g}\right.$ fresh weight $\left.[\mathrm{FW}]^{-1}\right)$, which is similar to previous observations in tomato and barley (Solomon and Oliver 2001; Vanacker et al. 1998). MDH activity in apoplast extracts $\left(0.008 \pm 0.001 \mu \mathrm{mol} \mathrm{min}{ }^{-1} \mathrm{~g}\right.$ $\mathrm{FW}^{-1}$ ) was less than $0.2 \%$ of the activity observed in leaf ho-

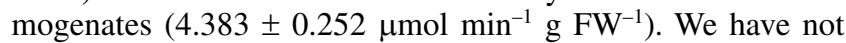
found any previous reports on $\mathrm{MDH}$ activity in tomato leaf and apoplast extracts; however, similar values have been obtained using $\mathrm{MDH}$ as a marker of cytoplasmic contamination in pea (Aked and Hall 1993), barley (Tetlow and Farrar 1993), and Brassica napus (Husted and Schjoerring 1995). Both leaf and apoplast extracts supported $\mathrm{MDH}$ and G6PDH activity when spiked with purified enzymes, and activity followed a typical kinetic curve (not shown), confirming that the low levels of activity observed in apoplast extracts were not due to inhibition. We used protein gel electrophoresis to show that the band corresponding to the 55-kDa large subunit of Rubisco was present in samples from whole-leaf extracts but absent from apoplast extracts (Lee et al. 2004) (data not shown). Collectively, these results confirm that the infiltration-centrifugation method used in this study generates apoplast extracts with minimal cytoplasmic contamination. The contents of the tomato apoplast are diluted between two- and threefold by the infiltration procedure $(2.5 \pm 0.35$, calculated as described below; data from three independent experiments). Consequently, apoplast extracts were freeze-dried and concentrated twofold for the growth and gene expression assays described below ("full-strength" apoplast). The $\mathrm{pH}$ of concentrated apoplast extracts was approximately 6 to 6.5 .

P. syringae pv. tomato DC3000 multiplied faster in apoplast extracts than in minimal media such as M9-glucose (Fig. 1). The generation time of $P$. syringae pv. tomato DC3000 in tomato apoplast extracts was approximately $2.5 \mathrm{~h} 4$ to $8 \mathrm{~h}$ after inoculation, compared with $3 \mathrm{~h}$ during the same time period in M9. $P$. syringae pv. tomato DC3000 typically displayed a longer lag phase in apoplast extracts than in the rich bacteriological medium Luria-Bertani (LB), in which it had a generation time of $2 \mathrm{~h} 2$ to $6 \mathrm{~h}$ after inoculation.

\section{Apoplast extracts from tobacco and tomato support the growth of a nonhost pathogen and a nonpathogenic bacterium.}

We compared the growth of $P$. syringae pv. tomato DC3000 in LB, M9, and apoplast extracts with the growth of two other plant-colonizing bacteria: the nonpathogen $P$. fluorescens SBW25 and the tobacco pathogen $P$. syringae pv. tabaci 11528. P. fluorescens SBW25 multiplied faster and to higher cell densities than either $P$. syringae strain in synthetic media (Fig. 1C and D), with generation times of approximately 1.5 and $2.4 \mathrm{~h}$ in LB and M9, respectively. P. syringae pv. tabaci 11528 grew very slowly in M9, with a generation time of $4.3 \mathrm{~h}$ 4 to $8 \mathrm{~h}$ after inoculation. However, all three strains displayed similar generation times of 2 to $2.5 \mathrm{~h}$ in tomato and tobacco apoplast extracts (Fig. 1A and B), and there was no significant difference in the growth rates of $P$. syringae pv. tomato DC3000 and P. fluorescens 2 to $6 \mathrm{~h}$ after inoculation ( $\alpha=0.05$; Tukey-Kramer honestly significant difference).

The growth of bacteria in tomato and tobacco apoplast extracts is in marked contrast to their growth in planta. We inoculated all three strains into tomato and tobacco leaves at $10^{5}$ and $10^{8} \mathrm{CFU} \mathrm{ml} \mathrm{m}^{-1}$ and monitored symptoms and bacterial growth over 7 days. As expected, both $P$. syringae pv. tomato DC3000 and $P$. syringae pv. tabaci 11528 caused complete collapse of inoculated leaf tissue within $24 \mathrm{~h}$ after inoculation at $10^{8} \mathrm{CFU}$ $\mathrm{ml}^{-1}$, and both strains multiplied to high levels when inocu- lated at $10^{5} \mathrm{CFU} \mathrm{ml}{ }^{-1}$ in their respective host plants. $P$. fluorescens SBW25 had no visible effect on leaves and failed to grow in either plant. P. syringae pv. tomato DC3000 was unable to grow in tobacco and did not cause visible necrosis when inoculated at low cell densities. However, P. syringae pv. tabaci 11528 multiplied approximately 10-fold over 7 days in tomato and caused a small amount of visible necrosis (data not shown). The observation that both the nonpathogen $P$. fluorescens SBW25 and nonhost strains of $P$. syringae can grow well in apoplast extracts from resistant plants supports the hypothesis that the ability of $P$. syringae to initiate infection in tobacco and tomato is determined primarily by its ability to overcome or tolerate induced host defenses, rather than tolerance toward preformed inhibitors or the ability to use nutrients present in the plant apoplast.

\section{Tomato apoplast extracts induce $h r p$ expression in vitro.}

Having shown that tomato apoplast extracts can be used to support bacterial growth in vitro, we then examined whether bacteria cultured in apoplast extracts displayed properties similar to bacteria colonizing the leaf apoplast. One trait known to be upregulated in apoplast-colonizing $P$. syringae is the hrpencoded TTSS. hrp gene expression is upregulated within minutes after infiltration of bacteria into plant leaves and can be induced in vitro in $h r p$-inducing medium (HIM), but is repressed in rich media such as LB (Brown et al. 2001; Hu et al. 2001; Preston 2000; Rahme et al. 1992; van Dijk et al. 1999; Xiao et al. 1992). We tested whether tomato apoplast extracts induced hrp expression using $P$. syringae pv. tomato DC3000 (pGFPGUS::hrpA), which contains a transcriptional fusion between the $h r p A$ promoter and uidA ( $\beta$-glucuronidase [GUS]) (Jackson et al. 2005). Expression of $h r p$ in apoplast extracts was higher than expression in LB but lower than expression in HIM (Fig. 2). Our results are similar to results reported by Xiao and associates (1992), who observed that the hrp genes of $P$. syringae pv. syringae 61 were upregulated when bacteria were incubated in tobacco leaf sap extracts, but to a lesser extent than in minimal M63M medium (M63 salts plus mannitol).

Differences in $h r p$ expression between apoplast extracts and HIM could be linked to a range of factors, including $\mathrm{pH}$, osmolarity, catabolite repression, nitrogen availability, and growth

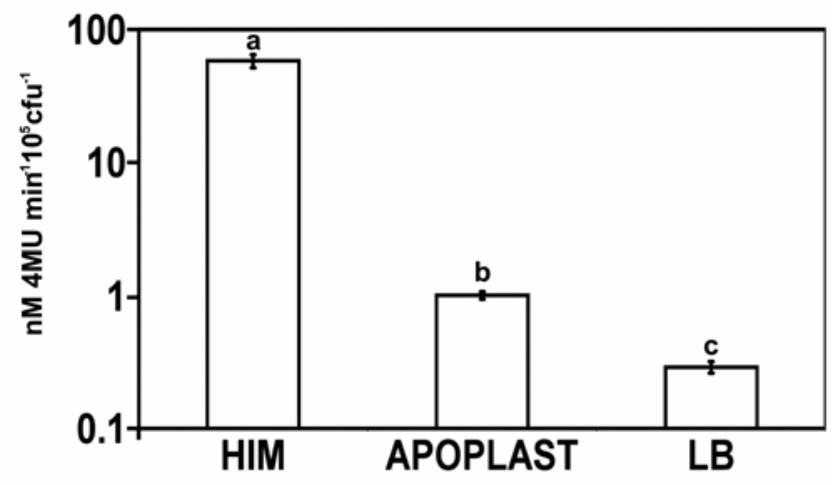

Fig. 2. hrp gene expression in apoplast extracts and synthetic media. $h r p A$ expression was determined by $\beta$-glucuronidase (GUS) activity in $h r p$-inducing medium (HIM), full-strength tomato apoplast extract (APOPLAST), and rich medium Luria-Bertani (LB). Strain Pseudomonas syringae pv. tomato DC3000 (pGFPGUS::hrpA) was grown in each medium at $28^{\circ} \mathrm{C}$ for $6 \mathrm{~h}$, and GUS activity was measured as described by Jackson and associates (2005). One-way analysis of variance and Tukey-Kramer honestly significant difference mean comparison test revealed significant differences in hrpA gene expression between each medium $(P<0.0001$; df $=2 ; \alpha=0.01$; JMP software). Values shown are the means and standard errors of three replicates on a log scale. The graph shows the results from one experiment. Three independent experiments were performed with similar results. 
rate (Huynh et al. 1989; Rahme et al. 1992; Xiao et al. 1992). Although HIM induces high levels of $h r p$ expression, it is a poor growth medium for $P$. syringae, which has a generation time of $12.5 \mathrm{~h} 4$ to $8 \mathrm{~h}$ after inoculation into HIM. In contrast, apoplast extracts provide an environment that both induces hrp expression and supports rapid multiplication of $P$. syringae.

\section{Carbon-utilization profiling}

\section{of genome-sequenced Pseudomonas spp.}

The differential results obtained for $P$. syringae and $P$. fluorescens in in vitro growth assays could be due to differences in the ability of these bacteria to use metabolites present in apoplast extracts and synthetic media (Misaghi and Grogan 1969; Sands et al. 1970). We used Biolog GN2 MicroPlate (Biolog GN2) technology to generate carbon utilization profiles for $P$. syringae pv. tomato DC3000, P. syringae pv. tabaci 11528, $P$. fluorescens SBW25, and 10 additional genomesequenced Pseudomonas spp. isolated from a range of ecological niches, allowing us to i) compare carbon utilization by these well-characterized strains, ii) confirm that the genomesequenced Pseudomonas strains have properties similar to those previously described for taxonomically related strains, iii) investigate whether $P$. syringae strains show distinctive patterns of nutrient utilization that could be linked to adaptation to growth in the apoplast and on leaf surfaces, and iv) interpret data from nutrient utilization analyses in the context of genome sequence data and functional genomic analyses. Four of the strains tested are plant pathogens that colonize the apoplast of diverse host plants ( $P$. syringae pv. tomato DC3000, $P$. syringae pv. syringae $\mathrm{B} 728 \mathrm{a}, P$. syringae pv. tabaci 11528 , and $P$. syringae pv. phaseolicola 1448A); six are nonpathogenic
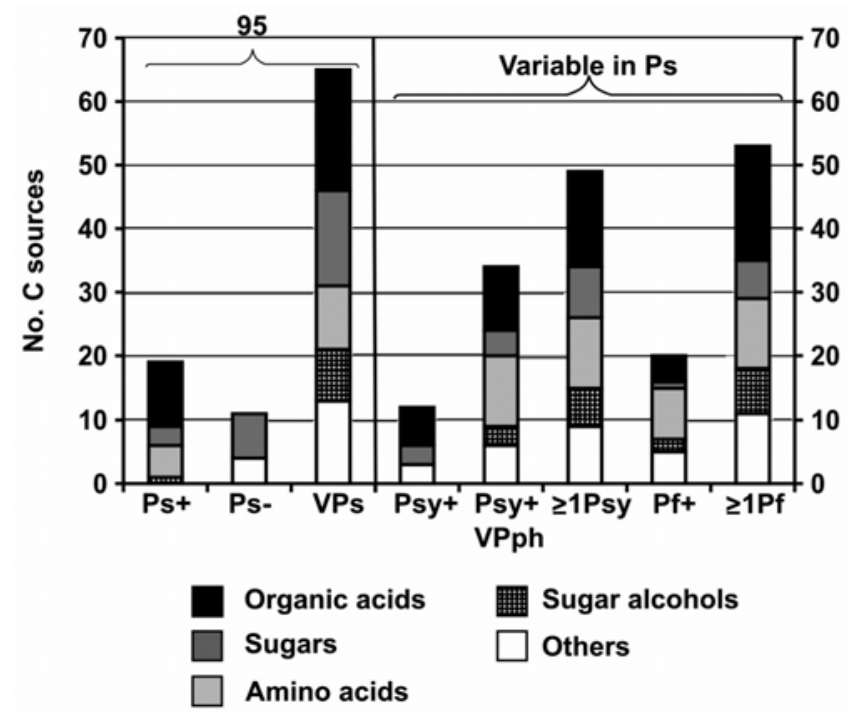

Fig. 3. Comparative analysis of carbon source utilization by Pseudomonas spp. Biolog GN2 plates were used to profile carbon assimilation by 13 model Pseudomonas strains: Pseudomonas syringae pv. tomato DC3000, P. syringae pv. syringae $\mathrm{B} 728 \mathrm{a}$, P. syringae pv. tabaci 11528, P. syringae pv. phaseolicola 1448A, P. fluorescens Pf-5, P. fluorescens PfO-1, P. fluorescens SBW25, $P$. putida KT2440, . putida $\mathrm{F} 1$, $P$. aeruginosa $\mathrm{PA} 14$, . aeruginosa PAO1, P. entomophila L48, and P. mendocina ymp. The first three bars starting from the left show the number of carbon sources that are positive for all 13 Pseudomonas strains (Ps+), negative for all Pseudomonas strains (Ps-), and variable for all Pseudomonas strains (VPs), which equate to a total of 95 carbon sources. Bars on the right depict the distribution of the variable carbon sources across different groups: substrates positive for all $P$. syringae strains (Psy+); positive for $P$. syringae pv. tomato DC3000, P. syringae pv. syringae $\mathrm{B} 728 \mathrm{a}$, and $P$. syringae $\mathrm{pv}$. tabaci 11528 , and variable in $P$. syringae pv. phaseolicola 1448A (Psy+, VPph); positive for at least one $P$. syringae strain ( $\geq 1 \mathrm{Psy}$ ); positive for all P. fluorescens strains $(\mathrm{Pf}+)$; and positive for at least one $P$. fluorescens strain ( $\geq 1 \mathrm{Pf})$. environmental bacteria isolated from soil, water, leaf surfaces, and the rhizosphere (P. fluorescens Pf- 5, P. fluorescens PfO-1, $P$. fluorescens SBW25, $P$. putida KT2440, $P$. putida $\mathrm{F} 1$, and $P$. mendocina ymp); two are opportunistic pathogens isolated from clinical samples ( $P$. aeruginosa PA14 and $P$. aeruginosa PAO1); and one is an insect pathogen (P. entomophila L48).

Biolog GN2 plates provide a 96-well format in which each well contains a unique carbon source and the metabolic indicator tetrazolium violet. Reduction of tetrazolium violet indicates that organisms are able to metabolize a specific carbon source. This assay, also known as a Phenotype MicroArray (Bochner et al. 2001), or phenoarray, reports on the process of metabolism rather than growth. The results obtained for each strain were consistent with previous descriptions of each species or pathovar in studies that have tested a large number of strains (Braun-Kiewnick and Sands 2001; Güven et al. 2004; Jones et al. 1993; Misaghi and Grogan 1969; Sands et al. 1970; Young and Triggs 1994), confirming that these genome-sequenced strains are fairly representative of corresponding taxonomic groups. However, care must be taken in drawing direct correlations between our results and previous studies, because many of the published analyses of nutrient utilization by $P$. syringae are based on the ability of bacteria to multiply on nutrients as sole carbon or nitrogen source rather than their metabolic activity when incubated with specific metabolites.

An overview of the nutrient utilization results obtained for all Pseudomonas spp. is provided in Figure 3. Results obtained for $P$. syringae pv. tomato DC3000 are shown in detail in Table 1 , grouped in relation to the distribution of nutrient utilization abilities in Pseudomonas spp. and nutrient assimilation during growth in synthetic media and apoplast extracts, which was determined using the assay described in the following section. A full set of nutrient utilization results for all strains is provided in Supplementary Table S1. All 13 strains used a common set of 19 substrates as carbon sources, which included three sugars, 10 organic acids, five amino acids, and one sugar alcohol (Fig. 3, Ps+; Table 1, group 1). However 65 carbon sources showed a variable distribution among strains (Fig. 3, VPs). The $P$. syringae strains generally showed much greater consistency than $P$. fluorescens in the substrates that they used. $P$. syringae pv. tomato $\mathrm{DC} 3000$, , syringae pv. syringae $\mathrm{B} 728 \mathrm{a}$, and $P$. syringae pv. tabaci 11528 used 53 common substrates (Fig. 3, Ps+ and Psy+ VPph; Table 1, groups 1, 2, and 3) out of 68 substrates that were used by at least one strain of $P$. syringae (Fig. 3 , Ps+ and $\geq 1$ Psy) compared with the 39 common substrates used by all three strains of P. fluorescens (Fig. 3, Ps+ and Pf+). Almost all of the nutrient utilization activities present in $P$. syringae pv. tomato DC3000 and other $P$. syringae strains correspond to metabolites known to be present in plant tissues, or specifically in the plant apoplast (Table 1).

P. syringae pv. phaseolicola 1448A had the most restricted nutrient utilization range of all strains tested and failed to use 22 substrates that were used by the other three $P$. syringae strains (Table 1, group 3). All four P. syringae strains failed to use hydroxy-L-proline, putrescine, and 2-aminoethanol, which were positive for all or almost all other Pseudomonas strains tested. However, three or four of the $P$. syringae strains tested used carbon sources that were used by only a small number of the other Pseudomonas tested, including sucrose, D-galactose, D-raffinose, D-sorbitol, myo-inositol, D-glucuronic acid, and Dglucuronamide.

Inhibition assays identify apoplast-induced carbon source utilization mechanisms in $P$. syringae pv. tomato $\mathrm{DC} 3000$.

Apoplast growth assays and nutrient utilization profiling results support the idea that $P$. syringae pv. tomato DC3000 and other $P$. syringae strains are adapted to use carbon sources that 
are abundant in the plant apoplast, but do not show which nutrient utilization pathways are active in $P$. syringae during apoplast colonization. We used Biolog GN2 assays as the basis for a protocol that can be used to identify which nutrient utilization pathways are active in bacteria grown in defined media or apoplast extracts. We cultured bacteria in LB, HIM, or apoplast extracts for $2 \mathrm{~h}$ to allow bacteria to adapt to the nutritional environment present in each medium and then treated bacteria with tetracycline, a bacteriostatic inhibitor of protein synthesis (Chopra and Roberts 2001), prior to inoculation into GN2 plates. Inhibitor treatment prevents bacteria from expressing new proteins to adapt to novel carbon sources but does not block the metabolic activity needed to reduce tetrazolium violet in the Biolog GN2 assay. Therefore, the results reflect which nutrient utilization pathways are active in the pretreatment media. Ihssen and Egli (2005) independently developed a similar assay, which uses chloramphenicol as the inhibitor, to distinguish repressed and induced catabolic functions in Escherichia coli.
Apoplast inhibitor-treated bacteria were able to use 22 substrates as carbon sources following inhibitor treatment, whereas LB inhibitor-treated bacteria used 17 and HIM inhibitor-treated bacteria used 19 (Table 2 ). Inhibitor-treated bacteria consistently generated a weaker signal than uninhibited bacteria; therefore, it is possible that some negative results may be false negatives. However, two observations argue against this interpretation for most of the negative results listed in Tables 1 and 2. First, we did observe positive results for substrates that gave weak results before inhibition, such as turanose and trehalose; second, many of the substrates that failed to give a positive result following tetracycline treatment were the same substrates that gave the strongest results before tetracycline treatment, such as L-arabinose, D-mannitol, and D-gluconic acid.

Thirteen of the activities observed in apoplast-grown bacteria correspond to activities present in all Pseudomonas spp. or all Pseudomonas spp. except $P$. syringae pv. phaseolicola 1448A (Table 1). Eleven of these common substrates, including glu-

Table 1. Nutrient utilization results obtained for Pseudomonas syringae pv. tomato DC3000 from Biolog GN2 plates in relation to distribution of substrate utilization ability across Pseudomonas spp., induction in apoplast extracts, and presence of the substrate in plants

\begin{tabular}{|c|c|c|c|}
\hline \multirow[b]{2}{*}{ Group, distribution ${ }^{b}$} & \multicolumn{3}{|c|}{ Expression in synthetic media and apoplast extracts ${ }^{a}$} \\
\hline & Constitutive & Induced & Not expressed \\
\hline 1. P. syringae pv. tomato DC3000 and all other Pseudomonas strains tested & $\begin{array}{l}\text { D-glucose } \\
\text { D-mannose } \\
\alpha \text {-ketoglutaric acid } \\
\text { Succinic acid } \\
\text { Bromosuccinic acid } \\
\text { L-asparagine } \\
\text { L-aspartic acid } \\
\text { L-glutamic acid } \\
\gamma \text {-aminobutyric } \text { acid }^{\mathrm{c}}\end{array}$ & $\begin{array}{l}\text { Citric acid } \\
\text { D-fructose }\end{array}$ & $\begin{array}{l}\text { Pyruvic acid methyl ester } \\
\text { Acetic acid }^{\mathrm{d}} \\
\text { Cis-aconitic acid }^{\mathrm{d}} \\
\text { D-gluconic acid } \\
\beta \text {-hydroxybutyric acid } \\
\text { D,L-lactic acid } \\
\text { L-proline }^{\mathrm{c}} \\
\text { Glycerol }^{\mathrm{d}}\end{array}$ \\
\hline $\begin{array}{l}\text { 2. P. syringae pv. tomato } \mathrm{DC} 3000, \text { P. syringae pv. syringae } \mathrm{B} 728 \mathrm{a}, \\
\text { P. syringae pv. tabaci } 11528 \text { and } P \text {. syringae } \mathrm{pv} \text {. phaseolicola } 1448 \mathrm{~A}\end{array}$ & & $\begin{array}{l}\text { D-galactose } \\
\text { Formic acid }^{\mathrm{d}} \\
\text { Malonic acid }^{\mathrm{c}} \\
\text { Uridine }^{\mathrm{d}}\end{array}$ & $\begin{array}{l}\text { Tween } 40 \\
\text { L-arabinose }^{\mathrm{d}} \\
\text { Sucrose }^{\mathrm{c}} \\
\text { Succinic acid mono- } \\
\text { methyl ester } \\
\text { D-galactonic acid } \\
\text { lactone }^{\mathrm{d}} \\
\text { Quinic acid }^{\mathrm{d}} \\
\text { Succinamic acid }^{\mathrm{d}} \\
\text { Inosine }^{\mathrm{d}}\end{array}$ \\
\hline $\begin{array}{l}\text { 3. P. syringae pv. tomato } \mathrm{DC} 3000, P \text {. syringae pv. syringae } \mathrm{B} 728 \mathrm{a} \text { and } \\
\text { P. syringae pv. tabaci } 11528 \text {; not used by } P \text {. syringae pv. phaseolicola } 1448 \mathrm{~A}\end{array}$ & $\begin{array}{l}\text { L-alanine } e^{\mathrm{c}, \mathrm{g}} \\
\text { L-serine }^{\mathrm{c}, \mathrm{g}}\end{array}$ & $\begin{array}{l}\text { D-glucuronic acid } \\
\text { Glucuronamide } \\
\text { Glycyl-L-glutamic } \\
\text { acid }\end{array}$ & $\begin{array}{l}\text { Glycogen } \\
\text { D-arabitol } \\
\text { Myo-inositol }^{\mathrm{d}, \mathrm{f}} \\
\text { D-mannitol }^{\mathrm{d}, \mathrm{e}, \mathrm{f}} \\
\text { D-sorbitol }^{\mathrm{d}, \mathrm{f}} \\
\text { D-psicose } \\
\text { D-galacturonic acid } \\
\text { Glucosaminic acid }^{\mathrm{d}, \mathrm{f}} \\
\text { D-saccharic acid }^{\mathrm{d}, \mathrm{g}} \\
\text { L-alaninamide }^{\text {D-alanine }} \\
\text { L-alanyl-glycine }^{\mathrm{g}} \\
\text { L-histidine }^{\mathrm{c}, \mathrm{f}} \\
\text { L-leucine }^{\mathrm{c}, \mathrm{f}} \\
\text { L-ornithine }^{\mathrm{d}, \mathrm{f}} \\
\text { D-serine }^{\mathrm{f}} \\
\text { L-threonine }^{\mathrm{c}, \mathrm{f}}\end{array}$ \\
\hline $\begin{array}{l}\text { 4. P. syringae pv. tomato } \mathrm{DC} 3000 \text {; not used by } P \text {. syringae pv. syringae } \mathrm{B} 728 \mathrm{a} \text {; } \\
\text { P. syringae pv. tabaci } 11528 \text { or } P \text {. syringae pv. phaseolicola } 1448 \mathrm{~A}\end{array}$ & & $\begin{array}{l}\text { D-trehalose } e^{\mathrm{d}, \mathrm{f}} \\
\text { Turanose }^{\mathrm{e}, \mathrm{f}}\end{array}$ & \\
\hline
\end{tabular}

${ }^{a}$ Expression of nutrient utilization ability in P. syringae pv. tomato DC3000. Constitutive = positive in all media tested, including apoplast extracts; Induced $=$ expressed during growth in apoplast extracts, but not expressed in all media tested; and Not expressed = not expressed during growth in apoplast extracts.

${ }^{\mathrm{b}}$ Distribution of substrate utilization ability in 13 strains of Pseudomonas based on performance in Biolog GN2 plates.

${ }^{\mathrm{c}}$ Reported to be present in the plant apoplast or xylem sap (Bialczyk et al. 2004; Joosten et al. 1990; Satoh 2006; White 1981; this study).

${ }^{\mathrm{d}}$ Reported to be present in tomato plants or fruits (Fuchs and De Vries 1969; Moco et al. 2006; Overy et al. 2005; Schauer et al. 2005, 2006).

e Reported to be non-plant metabolizable or of fungal origin (Joosten et al. 1990; Lewis and Harley 1965).

${ }^{\mathrm{f}}$ Reported to give a negative result in 56 P. syringae pv. phaseolicola strains tested by Güven et al. (2004).

${ }^{\mathrm{g}}$ Reported to give a positive result in 56 P. syringae pv. phaseolicola strains tested by Güven et al. (2004). 
cose, citric acid cycle intermediates such as succinic acid and $\alpha$ ketoglutaric acid, and glucogenic amino acids, gave positive results in all treatments regardless of the presence of inhibitor (Table 2), which probably indicates that they correspond to metabolic pathways and uptake mechanisms that are constitutively active in $P$. syringae. In contrast, all nine of the substrates that were used during growth in apoplast extracts, and which corresponded to abilities that were variably distributed in Pseudomonas spp., were apoplast induced (Tables 1, groups 2, 3, and 4 (induced), and Table 2). Many of the utilization pathways active in apoplast inhibitor-treated bacteria correspond to metabolites known to be present in the tomato apoplast or xylem sap (Schauer et al. 2006; Solomon and Oliver 2002; White 1981) (Table 1).

\section{Incubation in apoplast extracts limits the use of specific nutrients.}

One observation made while developing apoplast-inhibitor assays was that the media used for pretreatment had a significant effect on the nutrient utilization profile obtained, even in the absence of inhibition. P. syringae pv. tomato DC3000 used 63 carbon sources when pretreated with LB (Table 2). However, when bacteria were pretreated with HIM or apoplast extracts, they failed to use specific substrates (Table 2). One possible explanation for this result could be that LB contains sufficient quantities of the substrate or related compounds to "pre-induce" certain pathways, thereby promoting higher levels of utilization activity when bacteria are transferred to Biolog GN2 plates. We examined whether substrate utilization could be restored to apoplast-grown bacteria by spiking apoplast extracts with "lost" substrates (glycogen, Tween 80, sorbitol, $\alpha$-ketobutyric acid, or urocanic acid) prior to transfer to Biolog GN2 plates. None of the carbon source spiking treatments induced bacteria to use the corresponding substrate, which indicates that this phenomenon is due to other factors, such as inhibitors present in apoplast extracts and the physiological status of HIM and apoplast-grown bacteria.

\section{$P$. syringae pv. tomato DC3000 uses amino acids that are abundant in the plant apoplast.}

Biolog GN2 plates contain only 10 of the 20 protein amino acids and only assess the use of amino acids as carbon sources, not as nitrogen sources. In order to systematically assess variation in amino acid utilization among genome-sequenced pseudomonads, we incubated 12 Pseudomonas strains previously tested in Biolog GN2 plates in minimal media supplemented with protein amino acids or the nonprotein amino acid GABA as sole carbon or nitrogen source and tetrazolium violet as an indicator of nutrient utilization. GABA was included because it has been shown to be an abundant amino acid in the tomato

Table 2. Phenoarray and phenoarray/inhibitor assays for carbon source utilization by Pseudomonas syringae pv. tomato DC3000

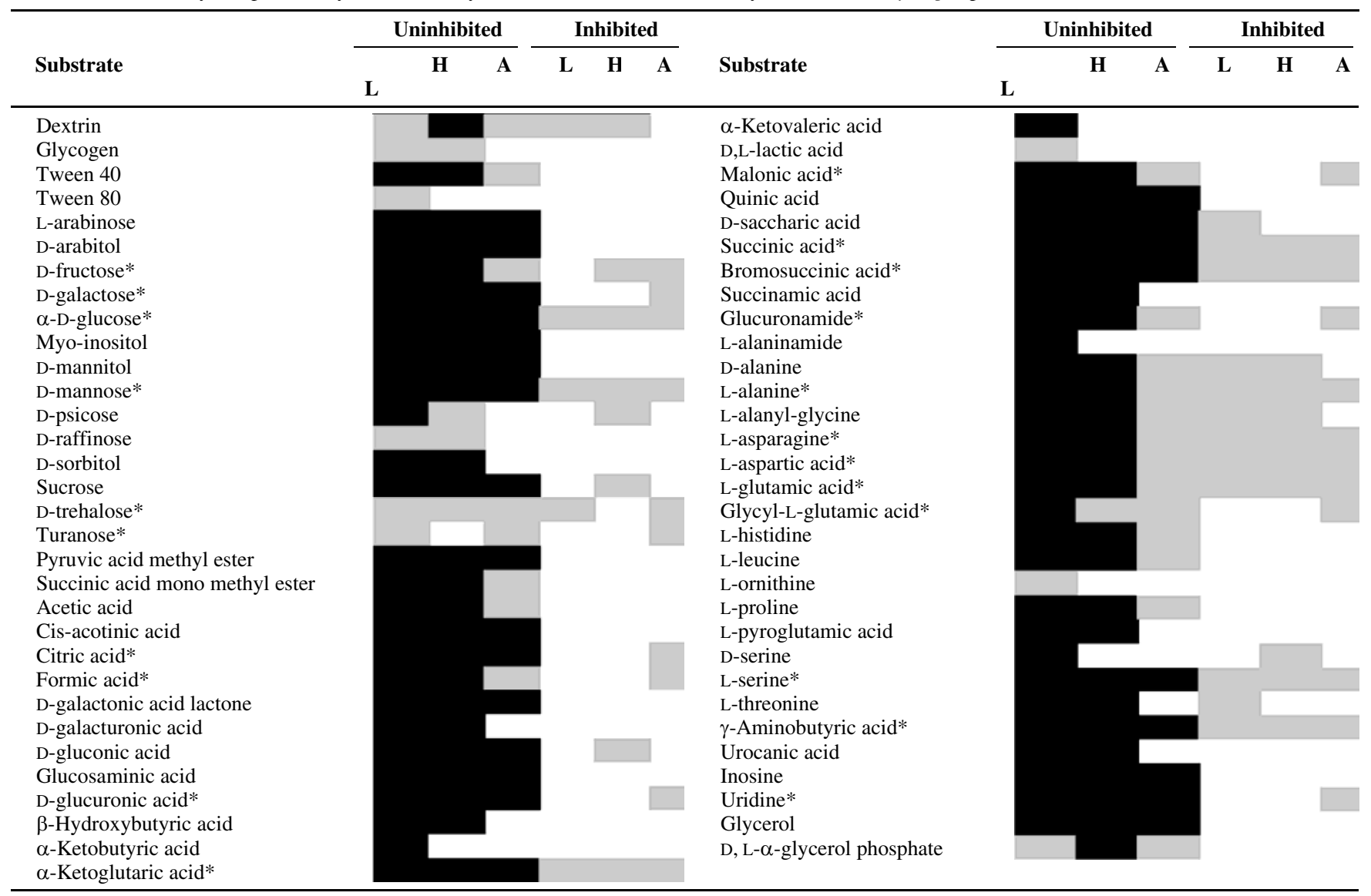

${ }^{\text {a }}$ Cells were incubated for $2 \mathrm{~h}$ in rich medium Luria-Bertani (LB) (L), hrp-inducing medium (HIM) (H), or tomato apoplast extracts (A) and then transferred to Biolog GN2 plates to assess the affect of different pre-treatments on subsequent substrate utilization. In inhibited treatments, tetracycline at $12.5 \mu \mathrm{g} / \mathrm{ml}$ was added to bacteria prior to inoculation into Biolog GN2 plates. Three replicates were obtained for each treatment, except uninhibited LB and HIM, where two replicates were obtained. Black boxes show positive values (average optical density at $620 \mathrm{~nm}\left[\mathrm{OD}_{620}\right]$ value $>0.2$ ), gray boxes show weak positive values $\left(0.2>\mathrm{OD}_{620}>0.05\right)$, and white boxes show negative values $\left(\mathrm{OD}_{620}<0.05\right)$. Asterisk $(*)$ indicates used by apoplast inhibitor-treated bacteria. The following substrates gave negative results in all assays: $\alpha$-cyclodextrin, $N$-acetyl-D-galactosamine, $N$-acetyl-D-glucosamine, adonitol, D-cellobiose, i-erythritol, L-fucose, gentiobiose, $\alpha$-D-lactose, lactulose, maltose, D-melibiose, $\beta$-methyl-D-glucoside, L-rhamnose, xylitol, $\alpha$-hydroxybutyric acid, $\gamma$-hydroxybutyric acid, p-hydroxyphenylacetic acid, itaconic acid, propionic acid, sebacic acid, glycyl-L-aspartic acid, hydroxy-L-proline, L-phenylalanine, D-L-carnitine, thymidine, phenylethylamine, putrescine, 2-aminoethanol, 2,3-butanediol, $\alpha$-D-glucose-1-phosphate, and D-glucose-6-phosphate. 
apoplast (Solomon and Oliver 2002). Tyrosine was excluded because of its low solubility in test media.

All Pseudomonas spp. gave clear positive results with L-asparagine, L-aspartic acid, GABA, L-glutamic acid, and L-glutamine as carbon and nitrogen sources and $\mathrm{L}$-arginine as a nitrogen source (Supplementary Tables S2 and S3). The remaining amino acids showed a variable pattern of utilization across the 12 Pseudomonas strains; however, in general, our results supported observations made by previous researchers showing that $P$. syringae strains showed a restricted ability to use amino acids when compared with other species of Pseudomonas (Sands et al. 1970; Sands and Zucker 1976), particularly when amino acids were provided as nitrogen sources. $P$. fluorescens Pf-5, P. fluorescens SBW25, P. putida F1, P. aeruginosa PA14, and $P$. entomophila L48 used all the tested amino acids as nitrogen sources. Biolog GN2 analyses and custom carbon source assays showed a high degree of agreement, although a small number of amino acids gave a weak or variable result in one assay and a negative result in the other assay.

Interestingly, all the $P$. aeruginosa and $P$. syringae strains tested gave weak or negative results in carbon utilization assays for leucine, isoleucine, and valine, which were used effectively by four or more of the nonpathogenic strains tested. All three $P$. syringae genomes lack the $b k d$ operon that encodes the branched chain keto acid dehydrogenase involved in the common pathway for branched chain amino acid degradation, and the associated regulatory gene $b k d R$ (Madhusudhan et al. 1999). The three $P$. syringae genomes also contain degenerate or rearranged versions of the liu cluster (liuRABCDE), which encodes proteins involved in the 3-methyl-crotonyl-CoA pathway for leucine degradation (Aguilar et al. 2006; ForsterFromme et al. 2006). P. syringae pv. syringae B728a contains a cluster with the organization liuRE $<774 \mathrm{nt}>A B C D ; P$. syringae pv. tomato DC3000 contains a cluster in which the genes
liuABCD are followed by two transposon genes and then liuER in the reverse orientation. P. syringae pv. phaseolicola $1448 \mathrm{~A}$ contains a liu cluster that has an organization similar to the liu cluster of $P$. syringae pv. syringae B728a, but with frameshift mutations in liuA and liuD.

One hypothesis that could account for the absence or degeneration of specific amino acid utilization pathways in $P$. syrin$g a e$ is that amino acid utilization matches amino acid availability in the plant environment. We performed high-performance liquid chromatography (HPLC) analyses to determine the amino acid composition of tomato apoplast extracts. Of the 20 protein amino acids, 19 could be detected, with the exception of arginine (Table 3). All six of the most abundant amino acids can be used as carbon and nitrogen sources by $P$. syringae strains, while many low-abundance amino acids correspond to amino acids that are used poorly, or not at all, by $P$. syringae, including leucine, isoleucine, and valine. However, $P$. syringae strains were able to use arginine, asparagine, histidine, and proline despite their low abundance in the apoplast (Table 3). Asparagine levels have been shown to increase in tomato plants infected with $P$. syringae (Olea et al. 2004), and proline and arginine levels may increase in plants undergoing $R$-genemediated defense responses or abiotic stress (Fabro et al. 2004, Skopelitis et al. 2006). Histidine is an expensive amino acid to synthesize (Akashi and Gojobori 2002) and is abundant in the leaf exudates of some plants, such as Arabidopsis (Pilot et al. 2004). It is likely that the ability to assimilate these amino acids plays an increasingly important role in later stages of infection or in other niches colonized by $P$. syringae.

We performed inhibition assays to identify amino acid utilization pathways that were active in apoplast-grown $P$. syringae pv. tomato DC3000. As expected, amino acids that were abundant in apoplast extracts $(>31 \mu \mathrm{M})$ were used as carbon sources following apoplast-inhibitor treatment (Table 3). The only low-

Table 3. Amino acid content of tomato leaf apoplast extracts in relation to the amino acid utilization profile of Pseudomonas syringae pv. tomato DC3000

\begin{tabular}{|c|c|c|c|c|c|c|c|}
\hline \multirow[b]{3}{*}{ Amino acid $^{b}$} & \multirow[b]{3}{*}{ Concentration $(\mu \mathrm{M})^{\mathrm{c}}$} & \multicolumn{6}{|c|}{ Phenoarray $^{a}$} \\
\hline & & \multicolumn{3}{|c|}{ Uninhibited } & \multicolumn{3}{|c|}{ Inhibited } \\
\hline & & LB & HIM & APO & LB & HIM & APO \\
\hline$\gamma$-Aminobutyric acid** & $575.5 \pm 82.9$ & + & + & + & $w^{d}$ & w & w \\
\hline Aspartic acid** & $145.4 \pm 45.5$ & + & + & + & $\mathrm{w}$ & + & w \\
\hline Glutamic acid** & $137.4 \pm 45.0$ & + & + & + & w & + & w \\
\hline Alanine* & $67.3 \pm 13.9$ & + & + & $\mathrm{w}$ & w & + & w \\
\hline Serine** & $51.2 \pm 12.3$ & + & + & + & w & + & $\mathrm{w}$ \\
\hline Glutamine** & $34.0 \pm 9.4$ & + & + & + & $w^{d}$ & $\mathrm{w}$ & $\mathrm{w}$ \\
\hline Leucine* & $31.8 \pm 5.7$ & $\mathrm{w}$ & $\mathrm{w}$ & w & - & - & - \\
\hline Glycine & $28.8 \pm 9.7$ & - & - & - & - & $-^{\mathrm{d}}$ & $-{ }^{\mathrm{d}}$ \\
\hline Phenylalanine* & $25.2 \pm 2.6$ & - & - & - & $-{ }^{\mathrm{d}}$ & - & - \\
\hline Methionine* & $24.9 \pm 8.6$ & $-^{\mathrm{d}}$ & - & - & - & - & - \\
\hline Valine & $24.7 \pm 0.1$ & - & $-{ }^{\mathrm{d}}$ & - & - & $-^{\mathrm{d}}$ & - \\
\hline Lysine* & $22.5 \pm 2.1$ & - & - & - & - & - & - \\
\hline Threonine & $22.0 \pm 8.9$ & - & - & - & - & - & - \\
\hline Isoleucine & $19.4 \pm 4.2$ & $-{ }^{\mathrm{d}}$ & - & - & $\mathrm{w}$ & - & - \\
\hline Tyrosine & $16.0 \pm 2.6$ & nt & nt & nt & nt & nt & nt \\
\hline Proline** & $12.8 \pm 1.7$ & + & + & w & $-^{\mathrm{d}}$ & w & $-^{\mathrm{d}}$ \\
\hline Asparagine $* *$ & $9.5 \pm 2.7$ & + & + & + & + & + & w \\
\hline Histidine* & $6.8 \pm 2.0$ & w & w & w & - & - & $-{ }^{\mathrm{d}}$ \\
\hline Arginine $* *$ & nd & w & $\mathrm{w}$ & $-{ }^{\mathrm{d}}$ & $-^{\mathrm{d}}$ & - & $-{ }^{\mathrm{d}}$ \\
\hline Cysteine & na & - & - & - & - & - & - \\
\hline Tryptophan & na & - & - & - & - & - & - \\
\hline
\end{tabular}

${ }^{a}$ P. syringae pv. tomato DC3000 was incubated for $2 \mathrm{~h}$ in Luria-Bertani (LB), hrp-inducing medium (HIM), or apoplast extract (APO), then resuspended in minimal medium containing $\mathrm{NH}_{4} \mathrm{Cl}$ as nitrogen source, an amino acid as carbon source, and tetrazolium violet as an indicator of amino acid utilization. In inhibitor treatments, cells were treated with tetracycline $(12.5 \mu \mathrm{g} / \mu \mathrm{l})$ before inoculation into test media. A minimum of two replicates were performed; $+=$ positive value (optical density at $\left.620 \mathrm{~nm}\left[\mathrm{OD}_{620}\right]>0.2\right)$, $\mathrm{w}=$ weak positive $\left(0.2>\mathrm{OD}_{620}>0.05\right),-=$ negative value $\left(\mathrm{OD}_{620}<0.05\right)$, and nt $=$ not tested..

b Asterisks: $*=$ the substrate was used as a nitrogen source by $P$. syringae pv. tomato DC 3000 in nitrogen utilization assays and $*=$ the substrate gave a weak signal in P. syringae pv. tomato DC3000 nitrogen utilization assays.

${ }^{c}$ Average concentration. Amino acid concentrations were determined by high-performance liquid chromatography (HPLC). The value shown is the average for three independent leaf apoplast extracts \pm standard deviation; na $=$ not analyzed by HPLC and nd = not detected by HPLC.

${ }^{\mathrm{d}}$ One replicate gave a positive result $\left(\mathrm{OD}_{620}>0.05\right)$. 
abundance amino acid used following inhibitor treatments was asparagine, which had a constitutively active utilization pathway in phenoarray analyses (Tables 1 and 2). Proline, histidine, and leucine assimilation pathways have been shown to be regulated by the level of the corresponding amino acid in the environment in other Pseudomonas spp. (Diaz-Perez et al. 2007; Nakada et al. 2002; Nishijyo et al. 1998; Vilchez et al. 2000; Zhang et al. 2006); therefore, the absence of histidine, proline, and leucine assimilation in inhibitor-treated, apoplast-grown bacteria is consistent with the low concentrations of these amino acids in apoplast extracts.

\section{The genome of $P$. syringae pv. phaseolicola 1448 A contains multiple frameshift mutations that correspond to the inability of this strain to use certain nutrients.}

We observed a high level of divergence between the results obtained for $P$. syringae pv. phaseolicola 1448A and the other $P$. syringae strains tested in both Biolog GN2 assays and custom amino acid assays. Our results are consistent with studies of nutrient utilization by other strains of $P$. syringae pv. phaseolicola (Table 1) (Güven et al. 2004; Young and Triggs 1994), except for a few minor discrepancies. Güven and associates (2004) reported that all $P$. syringae pv. phaseolicola strains tested gave positive results for D-saccharic acid, L-alanine, L-alanyl-glycine, and L-serine, which we scored as negative in Biolog GN2 assays. However, L-serine and L-alanine gave weak positive results in custom amino acid assays. Conversely, the same authors reported that $P$. syringae pv. phaseolicola strains were negative for $\alpha$-ketoglutaric acid and D,L-lactic acid, which were weak positives in our analyses. Finally, all the strains tested by Güven and associates were negative for L-histidine, which is consistent with our GN2 result but not with the weak or variable result we observed for L-histidine in custom amino acid assays. By combining our data with the data of Güven and associates, we were able to identify 15 metabolites that are not used or are very poorly used by the majority of $P$. syringae pv. phaseolicola strains but which are used by $P$. syringae pv. syringae $\mathrm{B} 728 \mathrm{a}$ and $P$. syringae pv. tomato DC3000 (myo-inositol, D-sorbitol, D-arabitol, D- mannitol, D-galacturonate, L-histidine, L-leucine, L-ornithine, Dserine, L-threonine, glucosaminic acid, D-gluconic acid, D-glucuronamide, $\alpha$-ketoglutaric acid, and D,L-lactic acid). Comparative analysis of genomic regions predicted to be involved in the assimilation of these metabolites shows that $P$. syringae pv. phaseolicola 1448A lacks or contains frameshift mutations in several genes that are predicted to be involved in the assimilation of these metabolites (Table 4).

\section{DISCUSSION}

Plant-pathogenic $P$. syringae strains are able to multiply to high levels on leaf surfaces and in the apoplastic fluid surrounding plant cells. In this study, we have explored the hypothesis that the nutrient utilization abilities of $P$. syringae correspond to nutrients available in plant tissues, specifically in the plant apoplast. We have profiled and compared the nutrient assimilation abilities of plant-pathogenic and nonplant pathogenic Pseudomonas spp., and we have used a modified version of phenoarray technology to identify nutrient assimilation pathways that are active in P. syringae pv. tomato DC3000 during growth in apoplast extracts. Finally, we have integrated nutrient profiling and nutrient assimilation data with knowledge of apoplast composition to show which of these pathways are unique to $P$. syringae or $P$. syringae pv. tomato DC3000, and to identify pathways that correspond to known apoplast metabolites. Our results demonstrate that $P$. syringae pv. tomato DC3000 expresses a combination of constitutive and plantinduced assimilation pathways that allow it to use nutrients that are abundant in apoplast extracts.

\section{$P$. syringae pv. tomato $\mathrm{DC} 3000$ is adapted to use nutrients that are abundant in the plant apoplast.}

$P$. syringae pv. tomato DC3000 and $P$. syringae pv. tabaci 11528 multiplied as rapidly as the nonpathogen $P$. fluorescens SBW25 in apoplast extracts despite performing relatively poorly in synthetic media. All three strains were able to use nutrients that are abundant in the tomato apoplast, including GABA, as-

Table 4. Inactivated and missing nutrient assimilation genes in Pseudomonas syringae pv. phaseolicola 1448A

\begin{tabular}{|c|c|c|c|}
\hline Metabolite $^{\mathrm{a}}$ & $\begin{array}{c}\text { Predicted } \\
\text { assimilation genes }^{b}\end{array}$ & $\begin{array}{l}\text { Predicted } \\
\text { function }^{c}\end{array}$ & $\begin{array}{l}\text { Possible explanation for lack of } \\
\text { function }^{d}\end{array}$ \\
\hline Myo-inositol & $\begin{array}{l}\text { iol operon (PSPTO_3500- } \\
\text { PSPTO_3492) }\end{array}$ & Inositol utilization & $\begin{array}{l}\text { Frameshifts in iolC }\left(\mathrm{PSPPH}{ }^{3194^{\mathrm{e}}}\right) \\
\text { and iolE (PSPPH_3193 })\end{array}$ \\
\hline D-sorbitol & polS (PSPTO_0363) & Sorbitol dehydrogenase & Frameshift in pols (PSPPH_4843 $\left.{ }^{\mathrm{e}}\right)$ \\
\hline D-arabitol/D-mannitol & xylB (PSPTO_2702) & Xylulokinase & $x y l B$ absent \\
\hline D-galacturonic acid & exuT (PSPTO_5219) & Galacturonate transporter & $\begin{array}{l}\text { Frameshift in regulatory gene } \\
\text { PSPPH_0309e adjacent to exuT } \\
\text { (PSPPH_0310) }\end{array}$ \\
\hline L-histidine & $\begin{array}{l}\text { hut operon (PSPTO_5270- } \\
\text { PSPTO_5278) }\end{array}$ & Histidine utilization & Frameshift in hutG(PSPPH_4868 $\left.{ }^{\mathrm{e}}\right)$ \\
\hline D-glucosaminic acid/D-serine & $\begin{array}{l}k d g K \text { operon (PSPTO_2775- } \\
\text { PSPTO_2782) }\end{array}$ & $\begin{array}{l}\text { Glucosaminic acid, D-serine and 2-dehydro- } \\
\text { 3-deoxy-D-gluconate utilization }\end{array}$ & $\begin{array}{l}\text { Transposase gene (PSPPH_2659) } \\
\text { inserted in promoter region of operon } \\
\text { (PSPPH_2660-PSPPH_2666) }\end{array}$ \\
\hline$\alpha$-Ketoglutaric acid & kgtP (PSPTO_4296) & $\alpha$-Ketoglutaric acid permease & Frameshift in $k g t P\left(\mathrm{PSPP} H \_4006^{\mathrm{e}}\right)$ \\
\hline \multirow[t]{2}{*}{ D,L-lactic acid } & $l d h A(\mathrm{PA} 2382)^{\mathrm{f}}$ & D-lactate dehydrogenase (NAD dependent) & ldhA absent \\
\hline & lldD (Psyr_0908) $)^{\mathrm{g}}$ & L-lactate dehydrogenase (FMN dependent) & lldD absent \\
\hline \multirow[t]{2}{*}{ L-leucine } & $\begin{array}{l}b k d \text { operon and } b k d R(\text { PA2247- } \\
\text { PA2249, PA2246) }\end{array}$ & Branched chain keto acid dehydrogenase & $b k d$ and $b k d R$ absent \\
\hline & liu operon (PA2016-PA2011) & 3-Methylcrotonyl-CoA pathway & $\begin{array}{l}\text { Frameshifts in liuA }\left(\mathrm{PSPPH} \_2628^{\mathrm{e}}\right) \\
\text { and } \text { liuD }\left(\mathrm{PSPPH} 2625^{\mathrm{e}}\right)\end{array}$ \\
\hline
\end{tabular}

\footnotetext{
${ }^{a}$ Metabolites that are used by some Pseudomonas spp. but not by P. syringae pv. phaseolicola.

${ }^{\mathrm{b}}$ Genes predicted to be involved in metabolite assimilation in either P. syringae pv. tomato DC3000 (PSPTO, NCBI reference sequence NC_004578), P. syringae pv. syringae B728a (Psyr, NC_007005), or P. aeruginosa PAO1 (PA, NC_002516).

${ }^{\mathrm{c}}$ Predicted function of genes listed in column 2.

${ }^{\mathrm{d}}$ Features of the genome sequence of $P$. syringae pv. phaseolicola 1448A (NC_005773) that could be linked to the poor ability of this strain to assimilate specific metabolites.

e Annotated as a pseudogene containing a genuine point mutation leading to a frameshift.

${ }^{\mathrm{f}}$ Not present in P. syringae pv. tomato DC3000 or P. syringae pv. syringae B728a.

g Not present in P. syringae pv. tomato DC3000.
} 
partate, glutamate, fructose, glucose, citrate, succinate, malate, and malonate (Bialczyk et al 2004; Joosten et al. 1990; Morris et al. 1995; Senden et al. 1992; Solomon and Oliver 2002; White 1981; this study). Apoplast inhibitor assays confirmed that pathways used to assimilate these nutrients were active in $P$. syringae pv. tomato DC3000 during growth in apoplast extracts. These results support the idea that $P$. syringae strains are well adapted for growth in the plant apoplast, but do not support the hypothesis that differences in apoplast composition and nutrient utilization make a significant contribution to differences in host specificity (Hildebrand 1972). However, P. syringae pv. tomato DC3000 did grow to a slightly higher population density than $P$. syringae pv. tabaci 11528 and P. fluorescens SBW25 in tomato apoplast extracts, which could indicate that $P$. syringae pv. tomato DC3000 assimilates some tomato metabolites that are not used by the other two strains. Further analyses of apoplast colonization using a wider range of hosts and $P$. syringae pathovars are needed to assess this question.

\section{Apoplast-induced nutrient assimilation pathways in $P$. syringae.}

The phenoarray inhibitor assay described in this article can be used to identify nutrient assimilation pathways that are constitutively active in a wide range of media and pathways that are specifically active in apoplast-grown bacteria. Interestingly, the apoplast-induced assimilation pathways in $P$. syringae pv. tomato DC3000 largely corresponded to abilities that were variably distributed across Pseudomonas spp., with the exception of fructose and citric acid. Expression of PSPTO0956, which encodes the IIBC component of the fructose-specific phosphotransferase system, has been shown to be upregulated in HIM versus the rich medium King's B (Lan et al. 2006), which confirms that the phenoarray inhibitor assay can be used to identify differentially expressed nutrient assimilation pathways. There are multiple citrate transport genes in the genome of $P$. syringae pv. tomato DC3000, including a homologue of the plant-induced citrate transporter Xcv3613 from the tomato pathogen Xanthomonas campestris pv. vesicatoria (Tamir-Ariel et al. 2007).

Apoplast-grown $P$. syringae pv. tomato DC3000 used two metabolites that were not used by the other $P$. syringae strains tested in this study, turanose and trehalose. Turanose does not occur naturally in plants (Sinha et al. 2002) and may be assimilated by a $P$. syringae pv. tomato DC3000-specific sugar utilization pathway that is induced by and acts on a range of sugars, as described for Klebsiella pneumoniae (Thompson et al. 2001). Trehalose utilization is a rare trait in $P$. syringae and was detected in only 1 of $101 P$. syringae strains tested by Misaghi and Grogan (1969) and none of the 86 P. syringae strains tested by Sands and associates (1970), although it is relatively common in P. fluorescens. Trehalose has been described as a carbon reserve, stress protectant, and carbon transport compound in plants (Ramalingam et al. 2006) and is present in tomato fruit (Schauer et al. 2006); therefore, trehalose utilization could be induced by the presence of plant-derived trehalose in apoplast extracts. It also is possible that trehalose utilization genes are induced by bacterial rather than plant-derived sugars. All three $P$. syringae genomes contain at least two putative trehalose synthases, including genes that are very similar to a trehalose synthase characterized from P. stutzeri (Jin-Ho et al. 2005); therefore, it is conceivable that $P$. syringae synthesizes trehalose as a compatible solute or carbon storage compound, which is released for catabolism during growth in apoplast extracts, either by cell lysis or in response to low nutrient availability.

One surprising omission from the list of apoplast-induced nutrient assimilation pathways observed in P. syringae pv. tomato DC3000 was sucrose, because sucrose has been shown to be present in the tomato apoplast (Joosten et al. 1990) and was used by uninhibited bacteria. Closer inspection of results showed that the average value obtained for sucrose was an optical density at $620 \mathrm{~nm}\left(\mathrm{OD}_{620}\right)$ of 0.04 , just below the threshold value of 0.05 . P. syringae pv. tomato DC3000 possesses three genes that encode levansucrase, which converts sucrose into the exopolysaccharide levan. It is conceivable that $P$. $s y$ ringae preferentially assimilates other sugars and organic acids when first transferred to apoplast extracts, and that apoplastic sucrose is converted to levan (Laue et al. 2006).

\section{Negative regulation of nutrient assimilation in $P$. syringae pv. tomato $\mathrm{DC} 3000$.}

Although we were able to identify a number of nutrient assimilation pathways that are constitutively or inducibly active in P. syringae pv. tomato DC3000 during growth in apoplast extracts, several metabolites that were good carbon sources for P. syringae pv. tomato DC3000 in vitro were not used following apoplast inhibitor treatment (Tables 1 and 2). The genome of $P$. syringae pv. tomato DC3000 contains putative transporters for many of these metabolites, including L-arabinose, Dmannitol, D-arabitol, glycerol, D-gluconic acid, sucrose, and inosine. It seems likely that $P$. syringae strains do encounter these metabolites in alternative habitats such as the leaf surface, plant tissues during later stages of infection, alternate host plants, or other ecological niches (Morris et al. 2007). It also is possible that $P$. syringae pv. tomato DC3000 encounters these metabolites in small quantities in the plant apoplast but preferentially assimilates abundant or energetically favorable carbon sources until these sources become limiting.

One result from our experiments that has significant implications for our understanding of nutrient assimilation by $P$. syringae and the application of phenoarray technology is the observation that $P$. syringae pv. tomato DC3000 used a restricted range of carbon and nitrogen sources when pre-incubated in apoplast extracts or HIM, even in the presence of the corresponding metabolite. One plausible explanation can be drawn from the work of King and associates (2004,2006), who used Biolog GN2 plates to demonstrate that variation in RpoS expression had a significant effect on the diversity of nutrient source utilization by E. coli. Stressors and nutrient limitations present in HIM and apoplast extracts could alter expression of nutrient assimilation genes and, thereby, limit adaptation to novel substrates.

\section{Prospects for future work.}

Although the time, effort, and biological resources required to isolate apoplast extracts are not trivial, apoplast extracts provide a more biologically relevant representation of nutrients present in the apoplast than artificial media such as HIM and could be used as a growth medium for transcriptomic, proteomic, and phenotypic analyses of $P$. syringae. However, it is important to emphasize that, although apoplast extracts provide a valuable hypothesis-generating tool, they cannot completely mimic environmental conditions present in planta, including the spatially structured environment provided by plant cell walls, or factors such as the nondiffusible cell wall signal that has been proposed to be involved in hrp induction in the plant pathogen Ralstonia solanacearum (Aldon et al. 2000; Brencic and Winans 2005). Furthermore, the composition of the apoplast is likely to change significantly in response to environmental factors such as light and stressors and in response to $P$. syringae infection. It will be important to assess how closely bacterial behavior in apoplast extracts mirrors bacterial behavior in planta.

The nutrient assimilation data described in this and previous studies supports the hypothesis that evolutionary processes such as negative selection, bottlenecks, and genetic drift have led to the loss of assimilation pathways that were present in the com- 
mon ancestor of $P$. syringae but which are not important for epiphytic or endophytic growth, whereas positive selection and lateral gene transfer have supported the retention and acquisition of genes that enhance growth in planta. Many of the nutrient assimilation abilities present in $P$. syringae appear to correspond to metabolites that i) are abundant in the apoplast of healthy host plants, ii) are energetically expensive to synthesize, iii) are present in alternate niches such as the leaf surface or guttation fluid, or iv) accumulate in plants during biotic and abiotic stress and senescence. However, detailed analyses of the composition of the apoplastic fluid, exudates, and surface metabolites of healthy and infected leaves, and of other plant tissues infected by $P$. syringae, and further analyses of $P$. syringae performance in apoplast extracts from diverse hosts are needed to fully assess the links between nutrient availability, nutrient assimilation, and bacterial fitness in different plant-associated niches.

The observation that $P$. syringae pv. phaseolicola $1448 \mathrm{~A}$ lacks many of the traits present in other $P$. syringae strains and shows evidence of recent gene loss raises intriguing questions about the evolution of this pathovar and the biology and ecology of $P$. syringae as a whole. Do the traits present in $P$. syringae pv. tomato DC3000 and absent from $P$. syringae pv. phaseolicola 1448A reflect specific characteristics of the hosts and niches colonized by these bacteria or of the pathogenicity factors used to manipulate and subvert host defenses? Or do these differences reflect differences in evolutionary and epidemiological history? Future studies can build on the results of these analyses to establish the genetic basis of strain and speciesspecific differences in nutrient utilization, to explore the evolutionary and environmental factors that affect the evolution of metabolism in P. syringae, and to analyze the nature, causality, and consequences of changes in apoplast composition that occur during infection and disease resistance.

\section{MATERIALS AND METHODS}

Plant material, bacterial strains, and growth conditions.

Five- to seven-week-old tomato (Solanum lycopersicum L. cv. Rio Grande) plants were used for apoplast extractions. Tomato seed were sown in a 3:1 soil:vermiculite mix and grown in a greenhouse under a 16-h photoperiod at 22 and $20^{\circ} \mathrm{C}$ day and night temperatures, respectively. In winter months, artificial light was provided with $400-\mathrm{W}$ sodium lamps.

The bacterial strains used in this study were $P$. aeruginosa PA01 and PA14 (Lee et al. 2006; Stover and Pham 2000), $P$. entomophila L48 (Vodovar et al. 2006), P. fluorescens PfO-1 (DOE Joint Genome Institution; GenBank CP000094), P. fluorescens Pf-5 (Paulsen et al. 2005), P. fluorescens SBW25 (Rainey and Bailey 1996), P. putida KT2440 (Nelson and Weinel 2002), P. putida F1 (DOE Joint Genome Institution; GenBank AALM00000000), P. mendocina ymp (DOE Joint Genome Institution; GenBank CP000712), P. syringae pv. phaseolicola 1448A (Joardar et al. 2005), P. syringae pv. syringae B728a (Feil et al. 2005), P. syringae pv. tabaci 11528 (American Type Culture Collection), P. syringae pv. tomato DC3000 (Buell et al. 2003), and P. syringae pv. tomato DC3000 (pGFPGUS::hrpA) (Jackson et al. 2005). Pseudomonas strains were routinely cultured at $28^{\circ} \mathrm{C}$ overnight on LB agar or broth (Sambrook and Russell 2001). LB broth, M9glucose (Sambrook and Russell 2001), and HIM (Mudgett and Staskawicz 1999) were used as growth media for testing substrate utilization, growth, and gene expression. Tetracycline was used at a final concentration of $12.5 \mu \mathrm{g} \mathrm{ml}^{-1}$.

\section{Extraction of whole leaf tissue.}

Leaves were detached from plants, placed in a mortar, and immediately frozen in liquid $\mathrm{N}_{2}$. Plant material was homoge- nized to a fine powder and mixed in a proportion of $1: 1 \mathrm{wt} / \mathrm{vol}$ with extraction buffer $(50 \mathrm{mM}$ potassium phosphate buffer, $\mathrm{pH}$ $7.0 ; 0.05 \% \beta$-mercaptoethanol; $10 \mathrm{mM}$ EDTA, $\mathrm{pH}$ 8.0; and one protease inhibitor tablet (Roche, Indianapolis, IN, U.S.A.) in $10 \mathrm{ml}$ ) and a small amount of acid-washed sand. The homogenate was centrifuged at $13,000 \mathrm{rpm}$ for $5 \mathrm{~min}$ at $4^{\circ} \mathrm{C}$ and the supernatant was transferred to $1.5-\mathrm{ml}$ microcentrifuge tubes and used immediately in enzymatic assays.

\section{Extraction of apoplastic fluid and estimation of apoplast dilution.}

Apoplastic fluid was extracted using vacuum infiltration as described elsewhere (Husted and Schjoerring 1995; Lohaus et al. 2001; Solomon and Oliver 2001), with slight modifications. Tomato leaves were cut directly from the plant, moistened with distilled water, and blotted dry in tissue paper. One to three leaves were placed in a 50-ml tip-sealed syringe containing $20 \mathrm{ml}$ of distilled water, and cycles of pressure and vacuum were applied until the leaves were completely infiltrated. The infiltrated leaves were blotted dry with paper tissue, rolled, and introduced into a 5-ml tip. The tip was introduced into a 50-ml conical tube (Corning, Corning, NY, U.S.A.) containing a 1.5$\mathrm{ml}$ collection tube and apoplast extract was collected by spinning the conical tubes at 2,000 rpm for $5 \mathrm{~min}$ at $4{ }^{\circ} \mathrm{C}$. The fraction collected in the $1.5-\mathrm{ml}$ tube was centrifuged again for 10 $\min$ at $3,000 \mathrm{rpm}$ at $4^{\circ} \mathrm{C}$. The supernatant was decanted to a clean $1.5-\mathrm{ml}$ tube and was either stored at $-80^{\circ} \mathrm{C}$ or freeze dried overnight using an ALPHA 2-4LD freeze drier (Christ, Osterode am Harz, Germany) to concentrate the sample to half the original volume. This concentrated sample was designated "full-strength" apoplast. Apoplast samples were filter sterilized using $0.2-\mu \mathrm{m}$ Whatman filters (Whatman, Maidstone, Kent, U.K.) for subsequent experiments.

The dilution of apoplastic metabolites caused by the infiltration technique was calculated as described by Solomon and Oliver (2001) and Lohaus and associates (2001). Preweighed leaves were infiltrated with a high-viscosity silicone fluid (AP100, polydimethymethylphenylsiloxane, density $1.07 \mathrm{~g} / \mathrm{cm}^{3}$; Wacker, Munich, Germany). The air volume was calculated as the increase in the weight of the leaves after the infiltration corrected with the density of the silicone oil $\left(V_{\text {air }} \mathrm{cm}^{3}\right.$ of air $\mathrm{g} \mathrm{FW}^{-}$ $\left.{ }^{1}\right)$. The apoplastic water volume was calculated by infiltrating preweighed leaves with indigo carmine $(50 \mathrm{mM}$ indigo-5,5' disulfonic acid, disodium salt) dissolved in $50 \mathrm{mM}$ phosphate buffer at $\mathrm{pH}$ 6.2. Immediately after infiltration, the leaves were blotted dry and reweighed. Assuming a leaf density of $1 \mathrm{~g} \mathrm{~cm}^{-1}$, the difference in weight before and after infiltration was used for calculation of the infiltration volume $\left(V_{i}\right)$. The dilution of the extracted dye $\left(D_{\text {dye }}\right)$ was determined spectrophotometrically at $610 \mathrm{~nm}$ by comparison of the absorbance of the extracted dye with known concentrations of indigo carmine. The apoplastic water volume was calculated using the following equation:

$$
\mathrm{V}_{\text {apo }}=\mathrm{D}_{\text {dye }} \times \mathrm{V}_{i} /\left(1-\mathrm{D}_{\text {dye }}\right)
$$

The equation for calculating the dilution factor of apoplast extracts is:

$$
\mathrm{F}_{d i l}=\left(\mathrm{V}_{\text {apo }}+\mathrm{V}_{\text {air }}\right) / \mathrm{V}_{\text {apo }}
$$

\section{Estimation of cytoplasmic contamination of apoplast extracts.}

Cytoplasmic contamination of apoplast extracts was examined by comparison of G6PDH and MDH activity in apoplast extracts and leaf homogenates (Lohaus et al. 1995; Solomon and Oliver 2001; Tetlow and Farrar 1993; Weimar and Rothe 1986). Apoplast extracts were prepared as above except that the leaves were infiltrated with the same buffer used for the extraction of leaf homogenates, and leaves were weighed be- 
fore and after infiltration. Between 1.5 and $2 \mathrm{ml}$ of apoplast extracts were obtained per $5 \mathrm{~g}$ of tomato leaves. G6PDH activity was assayed spectrophotometrically $(340 \mathrm{~nm})$ at $25^{\circ} \mathrm{C}$ in a medium containing $0.89 \mathrm{ml}$ of potassium phosphate buffer, $\mathrm{pH}$ $7.0(0.1 \mathrm{M}) ; 0.05 \mathrm{ml}$ of NADP $(6 \mathrm{mM})$, and $0.01 \mathrm{ml}$ of plant or apoplast extract in a total volume of $1 \mathrm{ml}$. The reaction was started by the addition of $0.05 \mathrm{ml}$ of glucose-6-phosphate ( 40 $\mathrm{mM})$. Activity was measured as the rate of increase in absorbance at $340 \mathrm{~nm}\left(\Delta \mathrm{A}_{340}\right)$ per minute. $\mathrm{MDH}$ activity was assayed spectrophotometrically $(340 \mathrm{~nm})$ at $25^{\circ} \mathrm{C}$ in a medium containing $0.2 \mathrm{ml}$ of MOPS buffer at $\mathrm{pH} 7.5(0.1 \mathrm{M}), 0.05 \mathrm{ml}$ of $\mathrm{NADH}(0.5 \mathrm{mM}), 0.01 \mathrm{ml}$ of plant or apoplast extract, and $0.54 \mathrm{ml}$ of distilled water in a total volume of $1 \mathrm{ml}$. The reaction was started by the addition of $0.2 \mathrm{ml}$ of oxaloacetic acid (2 mM). Activity was measured as $\Delta \mathrm{A}_{340}$ per minute. One unit is defined as the amount of enzyme that produces $1 \mu \mathrm{mol}$ of $\mathrm{NADPH}$ or $\mathrm{NAD}^{+}$per minute for G6PDH and $\mathrm{MDH}$, respectively. Enzymatic activity in spiked leaf and apoplast extracts with purified enzyme were performed by adding $1 \mu \mathrm{l}$ of a 5 $\mathrm{mg} / \mathrm{ml}$ solution of G6PDH or MDH (Roche) to the extract. The assays were performed three times and, when appropriate, an average value of the activity was obtained. Whole leaf and apoplast extracts were subjected to protein gel electrophoresis using Nu-PAGE precast gels according to the manufacturer's instructions (Invitrogen, Carlsbad, CA, U.S.A.). Gels were stained using Coomassie staining solution (Sambrook and Russell 2001). Protein size was estimated using the SeeBlue Plus2 prestained standard ladder (Invitrogen, Carlsbad, CA, U.S.A.)

\section{Bacterial growth assays.}

Single colonies of Pseudomonas strains grown on LB agar were used to inoculate LB broth cultures which were incubated with shaking $(200 \mathrm{rpm})$ at $28^{\circ} \mathrm{C}$ overnight. A $1.5-\mathrm{ml}$ aliquot of cell suspension was centrifuged and washed twice in $10 \mathrm{mM}$ $\mathrm{MgCl}_{2}, \mathrm{LB}$, or $\mathrm{M} 9$ and then resuspended in $0.5 \mathrm{ml}$ of apoplast extract, LB, or M9 respectively. Bacterial suspensions were adjusted to an $\mathrm{OD}_{620}$ of 0.05 . Aliquots of $150 \mu \mathrm{l}$ were inoculated into microplate wells (Falcon 3072, Becton Dickinson, Franklin Lakes, NJ, U.S.A.), along with blank controls for each medium (medium without bacteria) and the $\mathrm{OD}_{620}$ was measured over $24 \mathrm{~h}$ in a microplate spectrophotometer (MRXSpec; Dynatech Laboratory, Chantilly, VA, U.S.A.). Three replicates per strain and medium were performed for each experiment. At least three independent experiments were performed.

\section{Assessment of hrp gene expression.}

In vitro expression of $h r p A$, which encodes the pilin protein of the TTSS pilus, was tested using strain $P$. syringae pv. tomato DC3000 (pGFPGUS::hrpA), which contains a uidA fusion to the hrpA promoter (Jackson et al. 2005). P. syringae pv. tomato DC3000 (pGFPGUS::hrpA) was grown overnight at $28^{\circ} \mathrm{C}$ in LB broth supplemented with tetracycline. Cell aliquots of $1.5 \mathrm{ml}$ were harvested by centrifugation, washed once with LB, HIM, or $10 \mathrm{mM} \mathrm{MgCl}_{2}$, and then resuspended in LB, HIM, or fullstrength apoplast extract to an $\mathrm{OD}_{620}$ of 0.05 and incubated at $28^{\circ} \mathrm{C}$ with shaking. After $6 \mathrm{~h}$, the $\mathrm{OD}_{620}$ was determined and 2 $\mu \mathrm{l}$ of each of the cell suspensions was mixed with $80 \mu \mathrm{l}$ of extraction buffer $(50 \mathrm{mM} \mathrm{NaHPO}$, pH 7.0; $10 \mathrm{mM}$ 2-mercaptoethanol; $10 \mathrm{mM} \mathrm{Na} 2$ EDTA; $0.1 \%$ sodium lauryl sarcosine; and $0.1 \%$ Triton X-100) and $100 \mu \mathrm{l}$ of GUS assay buffer ( $2 \mathrm{mM} \mathrm{4-}$ methylumbelliferone- $\beta$-D-glucuronide [4MUG] dissolved in extraction buffer) in individual wells of a 96 -well microtiter plate (Falcon 3072). The plate was incubated in the dark at $37^{\circ} \mathrm{C}$ for $60 \mathrm{~min}$, at which time $10 \mu \mathrm{l}$ of each reaction was transferred to $190 \mu \mathrm{l}$ of stop buffer (0.2 M sodium carbonate). Uninoculated
LB, HIM, or full-strength apoplast extract ( $2 \mu \mathrm{l}$ each) were used as blank controls. GUS activity was measured by assessing the amount of fluorescent 4-methylumbelliferone released from hydrolysis of 4MUG (nonfluorescent). Fluorescence was measured using a POLARstar plate reader (BMG Laboratories, Offenburg, Germany) with an excitation wavelength of $370 \mathrm{~nm}$ and emission wavelength of $460 \mathrm{~nm}$. Enzyme activity was expressed as units of 7-hydroxy-4-methylcoumarin (4MU) $\min ^{-1} \times 10^{5}$ $\mathrm{CFU}^{-1}$. Three independent experiments were performed.

\section{BIOLOG GN2 and custom carbon and nitrogen phenoarrays.}

For comparative analyses between Pseudomonas strains, Biolog GN2 plates were inoculated following the manufacturer's instructions (BIOLOG, Hayward, CA, U.S.A.) with slight modifications. Bacteria were grown on LB agar at $28^{\circ} \mathrm{C}$ for 24 to $48 \mathrm{~h}$ and then resuspended in inoculating fluid (IF) (BIOLOG) to a final $\mathrm{OD}_{620}$ of 0.28 . Aliquots of $150 \mu \mathrm{l}$ were inoculated in each well using a multichannel pipettor. Plates were sealed with parafilm and incubated statically at $28^{\circ} \mathrm{C}$ for $24 \mathrm{~h} . \mathrm{OD}_{620}$ was read using a microplate reader (MRXSpec; Dynatech Laboratory). Each GN2 plate contained a negative control well containing medium without added carbon source. Activity in this well was used to estimate how much of the observed activity was due to metabolism of stored carbon reserves. $\mathrm{OD}_{620}$ values given in figure legends and discussed in the main text describe the value in the test well after subtraction of the negative control value.

Biolog GN2 plates also were used to assess the ability of $P$. syringae pv. tomato DC3000 to use a range of compounds as carbon sources following specific pretreatments. Bacteria were grown at $28^{\circ} \mathrm{C}$ in LB broth overnight. A $1.5-\mathrm{ml}$ aliquot of cell suspension was centrifuged and washed twice with $10 \mathrm{mM}$ $\mathrm{MgCl}_{2}, \mathrm{LB}$, or HIM and then resuspended in $2 \mathrm{ml}$ of apoplast extract, LB, or HIM, respectively. Bacteria were incubated in apoplast extract, LB, or HIM with shaking for $2 \mathrm{~h}$ at $28^{\circ} \mathrm{C}$, and then centrifuged and resuspended in approximately $20 \mathrm{ml}$ of IF (BIOLOG), to a final $\mathrm{OD}_{620}$ of 0.28 . Aliquots of $150 \mu \mathrm{l}$ of bacterial suspensions were inoculated into Biolog GN2 plates using a multichannel pipettor. In inhibition treatments, tetracycline was added to the bacterial suspension to a final concentration of $12.5 \mu \mathrm{g} / \mu \mathrm{l}$ after the 2-h pretreatment period and prior to inoculation into Biolog GN2 plates. Plates were incubated and scored as described above.

Custom carbon and nitrogen phenoarrays were designed following previously published methods (Bochner et al. 2001) with some modifications. Bacteria were grown overnight in LB, washed as described above, resuspended in apoplast extract, LB, or HIM, and incubated with shaking for $2 \mathrm{~h}$ at $28^{\circ} \mathrm{C}$. Cells were centrifuged and resuspended in twofold M9 that lacked either ammonium chloride or succinic acid and then 75$\mu \mathrm{l}$ aliquots were inoculated into microplate wells (Falcon 3072) containing $75 \mu \mathrm{l}$ of $40 \mathrm{mM}$ amino acid ( $\mathrm{pH} 7.0)$ and tetrazolium violet $(0.02 \%)$ as an indicator of carbon utilization. In inhibition treatments, tetracycline was added to the bacterial suspension to a final concentration of $12.5 \mu \mathrm{g} / \mu \mathrm{l}$ before inoculation into test plates. Ammonium chloride and succinic acid were used as positive controls and media lacking a carbon or nitrogen source was used as a negative control. Plates were incubated and scored as described above.

For the carbon spiking experiment, bacteria were prepared as described above and incubated for $2 \mathrm{~h}$ at $28^{\circ} \mathrm{C}$ with shaking in apoplast extract that was spiked with one of the following substrates: Tween 80, sorbitol, glycogen, $\alpha$-ketobutyric acid, or urocanic acid at $20 \mathrm{mM}$. After incubation, cells were centrifuged and resuspended in twofold M9 salts and $75 \mu \mathrm{l}$ was inoculated into microplate wells (Falcon 3072) containing 40 
$\mathrm{mM}$ of the corresponding carbon source and tetrazolium violet $(0.02 \%)$, to reach a final volume of $150 \mu \mathrm{l}$. Plates were incubated and scored as described above.

\section{HPLC analysis of amino acids in apoplast extracts.}

Apoplast extracts were obtained as described above and subjected to HPLC to detect protein amino acids and GABA. An internal standard mixture of Nor-valine and sarcosine was added to each sample prior to filtration through a 10,000 molecular weight cut-off centrifugal filter (Millipore Ultrafree-MC; Millipore, Billerica, MA, U.S.A.). Amino acid analysis was performed using an Agilent 1100 series HPLC with a G1327A autosampler and G1321A fluorescence detector. Samples were derivitized with ortho-phthalaldehyde for the primary amino acids and 9-fluorenylmethyl chloroformate for the secondary amino acids and $1 \mu \mathrm{l}$ was injected onto a Hypersil AA-ODS HPLC column (Agilent, Santa Clara, CA, U.S.A.) to resolve the derivitized amino acids. Results were integrated using Agilent ChemStation software with three-point calibration in each batch of samples using standard runs of 10, 25, and 100 picomoles. An internal standard of $10 \mathrm{mM}$ GABA was included for GABA analyses.

\section{Software and bioinformatic analyses.}

Statistical analyses of data including analysis of variance and comparison of means were carried out using JMP software (version 5; SAS Institute, Cary, NC, U.S.A.). Details of statistical analyses are presented in the figure legends. Bioinformatic analyses were performed using the KEGG PathwayDatabase (Kanehisa et al. 2006), the Pseudomonas Genome Database v2 (Winsor et al. 2005), and National Centre for Biotechnology Information (NCBI) databases. BLASTP and BLASTX analyses were performed against the Pseudomonas Genome Database v2 and the NCBI sequence database (Altschul et al. 1990).

\section{ACKNOWLEDGMENTS}

HPLC analyses were performed with the assistance of Tony Willis, Department of Biochemistry, University of Oxford. Arantza Rico was supported by Basque Government (Beca Para la Formacion de Investigadores_DK) and by BBSRC Grant BB/E007872/1. Gail Preston is a Royal Society University Research Fellow. We would like to thank Sarah Gurr, Robert Jackson, Andrew Howden, and Steinar Paulsen for comments on a draft of this manuscript.

\section{LITERATURE CITED}

Aguilar, J. A., Zavala, A. N., Diaz-Perez, C., Cervantes, C., Diaz-Perez, A. L., and Campos-Garcia, J. 2006. The atu and liu clusters are involved in the catabolic pathways for acyclic monoterpenes and leucine in Pseudomonas aeruginosa. Appl. Environ. Microbiol. 72:2070-2079.

Akashi, H., and Gojobori, T. 2002. Metabolic efficiency and amino acid composition in the proteomes of Escherichia coli and Bacillus subtilis. Proc. Natl. Acad. Sci. U.S.A. 99:3695-3700.

Aked, J., and Hall, J. L. 1993. Effect of powdery mildew infection on concentration of apoplastic sugars in pea leaves. New Phytol. 123:283-288.

Aldon, D., Brito, B., Boucher, C., and Genin, S. 2000. A bacterial sensor of plant cell contact controls the transcriptional induction of Ralstonia solanacearum pathogenicity genes. EMBO (Eur. Mol. Biol. Organ.) J. 19:2304-2314.

Alfano, J. R., and Collmer, A. 2004. Type III secretion system effector proteins: Double agents in bacterial disease and plant defense. Annu. Rev. Phytopathol. 42:385-414.

Altschul, S. F., Gish, W., Miller, W., Meyers, E. W., and Lipman, D. J. 1990. Basic Local Alignment Search Tool. J. Mol. Biol. 215:403-410.

Andrews, J. H., and Harris, R. F. 2000. The ecology and biogeography of microorganisms on plant surfaces. Annu. Rev. Phytopathol. 38:145-180.

Bialczyk, J., Lechowski, Z., and Dziga, D. 2004. Composition of the xylem sap of tomato seedlings cultivated on media with $\mathrm{HCO}_{3}{ }^{-}$and nitrogen source as $\mathrm{NO}_{3}{ }^{-}$or $\mathrm{NH}_{4}{ }^{+}$. Plant Soil 263:265-272.

Boch, J., Joardar, V., Gao, L., Robertson, T. L., Lim, M., and Kunkel, B. N. 2002. Identification of Pseudomonas syringae pv. tomato genes induced during infection of Arabidopsis thaliana. Mol. Microbiol. 44:73-88.

Bochner, B. R., Gadzinski, P., and Panomitros, E. 2001. Phenotype microarrays for high-throughput phenotypic testing and assay of gene function. Genome Res. 11:1246-1255.

Braun-Kiewnick, A., and Sands, D.C. 2001. Pseudomonas. Pages 84-120 in: Laboratory Guide for Identification of Plant Pathogenic Bacteria. N. W. Schaad, A. Jones, and W. Chun, eds. American Phytopathological Society Press, St. Paul, Minnesota.

Brencic, A., and Winans, S. C. 2005. Detection of and response to signals involved in host-microbe interactions by plant-associated bacteria. Microbiol. Mol. Biol. Rev. 69:155-194.

Brown, I. R., Mansfield, J. W., Taira, S., Roine, E., and Romantschuk, M. 2001. Immunocytochemical localization of HrpA and HrpZ supports a role for the Hrp pilus in the transfer of effector proteins from Pseudomonas syringae pv. tomato across the host plant cell wall. Mol. PlantMicrobe Interact. 14:394-404.

Buell, C. R., Joardar, V., Lindeberg, M., Selengut, J., Paulsen, I. T., Gwinn, M. L., Dodson, R. J., Deboy, R. T., Durkin, A. S., Kolonay, J. F., Madupu, R., Daugherty, S., Brinkac, L., Beanan, M. J., Haft, D. H., Nelson, W. C., Davidsen, T., Zafar, N., Zhou, L., Liu, J., Yuan, Q., Khouri, H., Fedorova, N., Tran, B., Russell, D., Berry, K., Utterback, T., Van Aken, S. E., Feldblyum, T. V., D’ Ascenzo, M., Deng, W., Ramos, A. R., Alfano, J. R., Cartinhour, S., Chatterjee, A. K., Delaney, T. P., Lazarowitz, S. G., Martin, G. B., Schneider, D. J., Tang, X., Bender, C. L., White, O., Fraser, C. M., and Collmer, A. 2003. The complete genome sequence of the Arabidopsis and tomato pathogen Pseudomonas syringae pv. tomato DC3000. Proc. Natl. Acad. Sci. U.S.A. 100:10181-10186.

Chisholm, S. T., Coaker, G., Day, B., and Staskawicz, B. J. 2006. Host-microbe interactions: Shaping the evolution of the plant immune response. Cell 124:803-814.

Chopra, I., and Roberts, M. 2001. Tetracycline antibiotics: Mode of action, applications, molecular biology, and epidemiology of bacterial resistance. Microbiol. Mol. Biol. Rev. 65:232-260.

Diaz-Perez, A. L., Roman-Doval, C., Diaz-Perez, C., Cervantes, C., SosaAguirre, C. R., Lopez-Meza, J. E., and Campos-Garcia, J. 2007. Identification of the $a c e A$ gene encoding isocitrate lyase required for the growth of Pseudomonas aeruginosa on acetate, acyclic terpenes and leucine. FEMS (Fed. Eur. Microbiol. Soc.) Microbiol. Lett. 269:309-316.

Fabro, G., Kovacs, I., Pavet, V., Szabados, L., and Alvarez, M. E. 2004. Proline accumulation and AtP5CS2 gene activation are induced by plant-pathogen incompatible interactions in Arabidopsis. Mol. PlantMicrobe Interact. 17:343-350.

Feil, H., Feil, W. S., Chain, P., Larimer, F., DiBartolo, G., Copeland, A., Lykidis, A., Trong, S., Nolan, M., Goltsman, E., Thiel, J., Malfatti, S., Loper, J. E., Lapidus, A., Detter, J.C., Land, M., Richardson, P. M., Kyrpides, N. C., Ivanova, N., and Lindow, S. E. 2005. Comparison of the complete genome sequences of Pseudomonas syringae pv. syringae B728a and pv. tomato DC3000. Proc. Natl. Acad. Sci. U.S.A. 102:11064-11069.

Forster-Fromme, K., Hoschle, B., Mack, C., Bott, M., Armbruster, W., and Jendrossek, D. 2006. Identification of genes and proteins necessary for catabolism of acyclic terpenes and leucine/isovalerate in Pseudomonas aeruginosa. Appl. Environ. Microbiol. 72:4819-4828.

Fuchs, A., and De Vries, F. W. 1969. Metabolism of radioactively labeled quinic acid and shikimic acid in healthy and Fusarium-infected tomato plants. Eur. J. Plant Pathol. 75:186-192.

Goatley, J. L., and Lewis, R. W. 1966. Composition of guttation fluid from rye, wheat and barley seedlings. Plant Physiol. 41:373-375.

Güven, K., Jones, J. B., Momol, M. T., and Dickstein, E. R. 2004. Phenotypic and genetic diversity among Pseudomonas syringae pv. phaseolicola. J. Phytopathol. 152:658-666.

Hildebrand, D. 1972. Tolerance of homoserine by Pseudomonas pisi and implications of homoserine in plant resistance. Phytopathology 63:301302.

Hirano, S. S., and Upper, C. D. 2000. Bacteria in the leaf ecosystem with emphasis on Pseudomonas syringae: A pathogen, ice nucleus, and epiphyte. Microbiol. Mol. Biol. Rev. 64:624-653.

Hu, W., Yuan, J., Jin, Q.L., Hart, P., and He, S. Y. 2001. Immunogold labeling of Hrp pili of Pseudomonas syringae pv. tomato assembled in minimal medium and in planta. Mol. Plant-Microbe Interact. 14:234-241.

Husted, S., and Schjoerring, J. K. 1995. Apoplastic pH and ammonium concentration in leaves of Brassica napus L. Plant Physiol. 109:1453-1460.

Huynh, T. V., Dahlbeck, D., and Staskawicz, B. J. 1989. Bacterial blight of soybean: Regulation of a pathogen gene determining host cultivar specificity. Science 245:1374-1377.

Ihssen, J., and Egli, T. 2005. Global physiological analysis of carbon- and energy-limited growing Escherichia coli confirms a high degree of catabolic flexibility and preparedness for mixed substrate utilization. Environ. Microbiol. 7:1568-1581.

Jackson, R. W., Preston, G. M., and Rainey, P. B. 2005. Genetic characteri- 
sation of Pseudomonas fluorescens SBW25 rsp gene expression in the phytosphere and in vitro. J. Bacteriol. 187:8477-8488.

Jin-Ho, L., Kwang-Ho, L., Chang-Gyeom, K., Se-Young, L., Geun-Joong, K., Young-Hoon, P., and Sung-Oh, C. 2005. Cloning and expression of a trehalose synthase from Pseudomonas stutzeri CJ38 in Escherichia coli for the production of trehalose. Appl. Microbiol. Biotechnol. 68:213-219.

Joardar, V., Lindeberg, M., Jackson, R. W., Selengut, J., Dodson, R., Brinkac, L. M., Daugherty, S. C., Deboy, R., Durkin, A. S., Giglio, M. G., Madupu, R., Nelson, W. C., Rosovitz, M. J., Sullivan, S., Crabtree, J., Creasy, T., Davidsen, T., Haft, D. H., Zafar, N., Zhou, L., Halpin, R., Holley, T. Khouri, H., Feldblyum, T., White, O., Fraser, C. M., Chatterjee, A. K., Cartinhour, S., Schneider, D. J., Mansfield, J., Collmer, A., and Buell, C. R. 2005. Whole-genome sequence analysis of Pseudomonas syringae pv. phaseolicola 1448A reveals divergence among pathovars in genes involved in virulence and transposition. J. Bacteriol. 187:6488-6498.

Jones, J. B., Chase, A. R., and Harris, G. K. 1993. Evaluation of the Biolog GN MicroPlate system for identification of some plant-pathogenic bacteria. Plant Dis. 77:553-558

Jones, J. D., and Dangl, J. L. 2006. The plant immune system. Nature 444:323-329.

Joosten, M. H. A. J., Hendrickx, L. J. M., and De Wit, P. J. G. M. 1990 Carbohydrate composition of apoplastic fluids isolated from tomato leaves inoculated with virulent or avirulent races of Cladosporium fulvum (syn. Fulvia fulva). Eur. J. Plant Pathol. 96:103-112.

Kanehisa, M., Goto, S., Hattori, M., Aoki-Kinoshita, K. F., Itoh, M., Kawashima, S., Katayama, T., Araki, M., and Hirakawa, M. 2006. From genomics to chemical genomics: New developments in KEGG. Nucleic Acids Res. 34:354-357.

King, T., Ishihama, A., Kori, A., and Ferenci, T. 2004. A regulatory tradeoff as a source of strain variation in the species Escherichia coli. J. Bacteriol. 186:5614-5620.

King, T., Seeto, S., and Ferenci, T. 2006. Genotype-by-environment interactions influencing the emergence of rpoS mutations in Escherichia coli populations. Genetics 172:2071-2079.

Lan, L., Deng, X., Zhou, J., and Tang, X. 2006. Genome-wide gene expression analysis of Pseudomonas syringae pv. tomato DC3000 reveals overlapping and distinct pathways regulated by hrpL and hrpRS. Mol. Plant-Microbe Interact. 19:976-987.

Laue, H., Schenk, A., Li, H., Lambertsen, L., Neu, T. R., Molin, S., and Ullrich, M. S. 2006. Contribution of alginate and levan production to biofilm formation by Pseudomonas syringae. Microbiology 152:2909-2918.

Lee, D. G., Urbach, J. M., Wu, G., Liberati, N. T., Feinbaum, R. L., Miyata, S., Diggins, L. T., He, J., Saucier, M., Deziel, E., Friedman, L., Li, L., Grills, G., Montgomery, K., Kucherlapati, R., Rahme, L. G., and Ausubel, F. M. 2006. Genomic analysis reveals that Pseudomonas aeruginosa virulence is combinatorial. Genome Biol. 7:R90.

Lee, S. J., Saravanan, R. S., Damasceno, C. M. B., Yamane, H., Kim, B. D., and Rose, J. K. C. 2004. Digging deeper into the plant cell wall proteome. Plant Physiol. Biochem. 42:979-988.

Lewis, D. M., and Harley, J. L. 1965. Carbohydrate physiology of mycorrhizal roots of beech. III. Movement of sugars between host and fungus. New Phytol. 64:256-269.

Lohaus, G., Pennewiss, K., Sattelmacher, B., Hussmann, M., and Muehling, K. H. 2001. Is the infiltration-centrifugation technique appropriate for the isolation of apoplastic fluid? A critical evaluation with different plant species. Physiol. Plant. 111:457-465.

Mackey, D., Belkhadir, Y., Alonso, J. M., Ecker, J. R., and Dangl, J. L. 2003. Arabidopsis RIN4 is a target of the type III virulence effector AvrRpt2 and modulates RPS2-mediated resistance. Cell 112:379-389.

Madhusudhan, K. T., Luo, J., and Sokatch, J. R. 1999. In vitro transcriptional studies of the bkd operon of Pseudomonas putida: L-branchedchain amino acids and D-leucine are the inducers. J. Bacteriol. 181:2889-2894

Misaghi, I., and Grogan, R. G. 1969. Nutritional and biochemical comparisons of plant-pathogenic and saprophytic fluorescent pseudomonads. Phytopathology 59:1436-1450.

Moco, S., Bino, R. J., Vorst, O., Verhoeven, H. A., de Groot, J., van Beek, T. A., Vervoort, J., and de Vos, C. H. 2006. A liquid chromatographymass spectrometry-based metabolome database for tomato. Plant Physiol. 141:1205-1218.

Morris, C. E., Kinkel, L. L., Xiao, K., Prior, P., and Sands, D. C. 2007. Surprising niche for the plant pathogen Pseudomonas syringae. Infect. Genet. Evol. 7:84-72.

Morris, V. L., Jackson, D. P., Grattan, M., Ainsworth, T., and Cuppels, D. A. 1995. Isolation and sequence analysis of the Pseudomonas syringae pv. tomato gene encoding a 2,3-diphosphoglycerate-independent phosphoglyceromutase. J. Bacteriol. 177:1727-1733.

Mudgett, M. B., and Staskawicz, B. J. 1999. Characterization of the Pseudomonas syringae pv. tomato AvrRpt2 protein: Demonstration of secre- tion and processing during bacterial pathogenesis. Mol. Microbiol. 32:927-941.

Nakada, Y., Nishijyo, T., and Itoh, Y. 2002. Divergent structure and regulatory mechanism of proline catabolic systems: characterization of the putAP proline catabolic operon of Pseudomonas aeruginosa PAO1 and its regulation by PruR, an AraC/XylS family protein. J. Bacteriol. 184:5633-5640.

Nelson, K. E., and Weinel, C. 2002. Complete genome sequence and comparative analysis of the metabolically versatile Pseudomonas putida KT2440. Environ. Microbiol. 4:799-808.

Nishijyo, T., Park, S. M., Lu, C. D., Itoh, Y., and Abdelal, A. T. 1998. Molecular characterization and regulation of an operon encoding a system for transport of arginine and ornithine and the ArgR regulatory protein in Pseudomonas aeruginosa. J. Bacteriol. 180:5559-5566.

Nomura, K., Melotto, M., and He, S. 2005. Suppression of host defense in compatible plant-Pseudomonas syringae interactions. Curr. Opin. Plant Biol. 8:361-368.

Olea, F., Perez-Garcia, A., Canton, F. R., Rivera, M. E., Canas, R., Avila, C., Cazorla, F. M., Canovas, F. M., and de Vicente, A. 2004. Up-regulation and localization of asparagine synthetase in tomato leaves infected by the bacterial pathogen Pseudomonas syringae. Plant Cell Physiol. 45:770-780.

Overy, S. A., Walker, H. J., Malone, S., Howard, T. P., Baxter, C. J., Sweetlove, L. J., Hill, S. A., and Quick, W. P. 2005. Application of metabolite profiling to the identification of traits in a population of tomato introgression lines. J. Exp. Bot. 56:287-296.

Paulsen, I. T., Press, C. M., Ravel, J., Kobayashi, D. Y., Myers, G. S., Mavrodi, D. V., DeBoy, R. T., Seshadri, R., Ren, Q., Madupu, R., Dodson, R. J., Durkin, A. S., Brinkac, L. M., Daugherty, S. C., Sullivan, S. A., Rosovitz, M. J., Gwinn, M. L., Zhou, L., Schneider, D. J., Cartinhour, S. W., Nelson, W. C., Weidman, J., Watkins, K., Tran, K., Khouri, H., Pierson, E. A., Pierson, L. S. I., Thomashow, L. S., and Loper, J. E. 2005. Complete genome sequence of the plant commensal Pseudomonas fluorescens Pf-5. Nat. Biotechnol. 23:873-878.

Pilot, G., Stransky, H., Bushey, D. F., Pratelli, R., Ludewig, U., Wingate, V. P. M., and Frommer, W. B. 2004. Overexpression of GLUTAMINE DUMPER1 leads to hypersecretion of glutamine from hydathodes of Arabidopsis leaves. Plant Cell 16:1827-1840.

Preston, G. M. 2000. Pseudomonas syringae pv. tomato: the right pathogen, of the right plant, at the right time. Mol. Plant Pathol. 1:263-275.

Rahme, L. G., Mindrinos, M. N., and Panopoulos, N. J. 1992. Plant and environmental sensory signals control the expression of hrp genes in Pseudomonas syringae pv. phaseolicola. J. Bacteriol. 174:3499-3507.

Rainey, P. B., and Bailey, M. J. 1996. Physical and genetic map of the Pseudomonas fluorescens SBW25 chromosome. Mol. Microbiol. 19:521-533.

Ramalingam, J., Pathan, M. S., Feril, O., Miftahudin, Ross, K., Ma, X. F., Mahmoud, A. A., Layton, J., Rodriguez-Milla, M. A., Chikmawati, T., Valliyodan, B., Skinner, R., Matthews, D. E., Gustafson, J. P., and Nguyen, H. T. 2006. Structural and functional analyses of the wheat genomes based on expressed sequence tags (ESTs) related to abiotic stresses. Genome 49:1324-1340.

Sambrook, J., and Russell, D. W. 2001. Molecular Cloning. Cold Spring Harbor Laboratory Press, Cold Spring Harbor, NY, U.S.A.

Sands, D. C., and Zucker, M. 1976. Amino acid inhibition of pseudomonads and its reversal by biosynthetically related amino acids. Physiol. Plant Pathol. 9:127-133

Sands, D. C., Schroth, M. N., and Hildebrand, D. 1970. Taxonomy of phytopathogenic pseudomonads. J. Bacteriol. 101:9-23.

Satoh, S. 2006. Organic substances in xylem sap delivered to aboveground organs by the roots. J. Plant Res. 119:179-187.

Schauer, N., Zamir, D., and Fernie, A. R. 2005. Metabolic profiling of leaves and fruit of wild species tomato: a survey of the Solanum lycopersicum complex. J. Exp. Bot. 56:297-307.

Schauer, N., Semel, Y., Roessner, U., Gur, A., Balbo, I., Carrari, F., Pleban, T., Perez-Melis, A., Bruedigam, C., Kopka, J., Willmitzer, L., Zamir, D., and Fernie, A. R. 2006. Comprehensive metabolic profiling and phenotyping of interspecific introgression lines for tomato improvement. Nat. Biotechnol. 24:447-454

Senden, M. H. M. N., Van der Meer, A. J. G. M., Limborgh, J., and Wolterbeek, H. T. H. 1992. Analysis of major tomato xylem organic acids and PITC-derivatives of amino acids by RP-HPLC and UV detection. Plant Soil 142:81-89.

Sinha, A. K., Hofmann, M. G., Romer, U., Kockenberger, W., Elling, L., and Roitsch, T. 2002. Metabolizable and non-metabolizable sugars activate different signal transduction pathways in tomato. Plant Physiol. 128:1480-1489.

Skopelitis, D. S., Paranychianakis, N. V., Paschalidis, K. A., Pliakonis, E. D., Delis, I. D., Yakoumakis, D. I., Kouvarakis, A., Papadakis, A. K., Stephanou, E. G., and Roubelakis-Angelakis, K. A. 2006. Abiotic stress 
generates ROS that signal expression of anionic glutamate dehydrogenases to form glutamate for proline synthesis in tobacco and grapevine. Plant Cell 18:2767-2781.

Solomon, P. S., and Oliver, R. P. 2001. The nitrogen content of the tomato leaf apoplast increases during infection by Cladosporium fulvum. Planta 213:241-249.

Solomon, P. S., and Oliver, R. P. 2002. Evidence that gamma-aminobutyric acid is a major nitrogen source during Cladosporium fulvum infection of tomato. Planta 214:414-420.

Solomon, P. S., Tan, K., and Oliver, R. P. 2003. The nutrient supply of pathogenic fungi: A fertile field for study. Mol. Plant Pathol. 4:203-210.

Stanier, R. Y., Palleroni, N. J., and Doudoroff, M. 1966. The aerobic pseudomonads: A taxonomic study. J. Gen. Microbiol. 43:159-271.

Stover, C. K., and Pham, X. Q. 2000. Complete genome sequence of Pseudomonas aeruginosa PA01, an opportunistic pathogen. Nature 406:95964.

Studholme, D., Downie, A., and Preston, G. 2005. Unique domain architectures in plant pathogenic Proteobacteria. BMC Genomics 6:17.

Tamir-Ariel, D., Navon, N., and Burdman, S. 2007. Identification of genes in Xanthomonas campestris pv. vesicatoria induced during its interaction with tomato. J. Bacteriol. 189:6359-6371.

Tetlow, I. J., and Farrar, J. F. 1993. Apoplastic sugar concentration and pH in barley leaves infected with brown rust. J. Exp. Bot. 44:929-936.

Thompson, J., Robrish, S. A., Pikis, A., Brust, A., and Lichtenthaler, F. W. 2001. Phosphorylation and metabolism of sucrose and its five linkageisomeric alpha-D-glucosyl-D-fructoses by Klebsiella pneumoniae. Carbohydr. Res. 331:149-161.

van Dijk, K., Fouts, D. E., Rehm, A. H., Hill, A. R., Collmer, A., and Alfano, J. R. 1999. The Avr (effector) proteins HrmA (HopPsyA) and AvrPto are secreted in culture from Pseudomonas syringae pathovars via the Hrp (Type III) protein secretion system in a temperature- and pH- sensitive manner. J. Bacteriol. 181:4790-4797.
Vanacker, H., Carver, T. L., and Foyer, C. H. 1998. Pathogen-induced changes in the antioxidant status of the apoplast in barley leaves. Plant Physiol. 117:1103-1114.

Vilchez, S., Manzanera, M., and Ramos, J. L. 2000. Control of expression of divergent Pseudomonas putida put promoters for proline catabolism. Appl. Environ. Microbiol. 66:5221-5225.

Vodovar, N., Vallenet, D., Cruveiller, S., Rouy, Z., Barbe, V., Acosta, C., Cattolico, L., Jubin, C., Lajus, A., Segurens, B., Vacherie, B., Wincker, P., Weissenbach, J., Lemaitre, B., Medigue, C., and Boccard, F. 2006. Complete genome sequence of the entomopathogenic and metabolically versatile soil bacterium Pseudomonas entomophila. Nat. Biotechnol. 24:673-679.

Weimar, M., and Rothe, G. 1986. Preparation of extracts from mature spruce needles for enzymatic analysis. Physiol. Plant 69:692-698.

White, M. C. 1981. Metal complexation in xylem fluid: I. Chemical composition of tomato and soybean stem exudate. Plant Physiol. 67:292300 .

Winsor, G. L., Lo, R., Sui, S. J., Ung, K. S., Huang, S., Cheng, D., Ching, W. K., Hancock, R. E., and Brinkman, F. S. 2005. Pseudomonas aeruginosa Genome Database and PseudoCAP: Facilitating communitybased, continually updated, genome annotation. Nucleic Acids Res. 33:338-343.

Xiao, Y., Lu, Y., Heu, S., and Hutcheson, S. W. 1992. Organization and environmental regulation of the Pseudomonas syringae pv. syringae 61 hrp cluster. J. Bacteriol. 174:1734-1741.

Young, J. M., and Triggs, C. M. 1994. Evaluation of determinative tests for pathovars of Pseudomonas syringae van Hall 1902. J. Appl. Bacteriol. 77:195-207.

Zhang, X.-X., George, A., Bailey, M. J., and Rainey, P. B. 2006. The histidine utilization (hut) genes of Pseudomonas fluorescens SBW25 are active on plant surfaces, but are not required for competitive colonization of sugar beet seedlings. Microbiology 152:1867-1875. 